\title{
دور وسائل الإعلام في هكافمة جرائم العنف
}

\author{
إعداد \\ د/خالد عبد الحميد كامل خريوش
}

ملخص البحث

يعود انتشار العنف وتأثنره علي أفراد المجتمع إلي المشكلات والصعاب التي يواجهونها ؛ ونظراً لضعف المستوي الثقافي وضيق الأفق المعلوماتي وقلة الخبرات الحياتية وعدم القدرة علي المواجهة والتحدي زاد تأثير العنف عليهم مما أدي في كثير من الأحيان إلي إصابتهم بالإحباط واليأس والثعور بالخوف مما هو قادم ؛ وخلاف ذللك لديهم إحساس بعدم الأمان ؛ لذا فان دور وسائل الإعلام هو غرس وانماء الثقة لديهم ، ومدهم بالسكينة والطمأنينة ، لهو من أهم الأدوار التي تؤديها أهم المؤسسات بالدول جميعاً ، حيث أن وسائل الإعلام يمكنها إختراق الأجواء وعبور المحيطات وإختيار الجبال والنفاذ من الجدران وتعمل بسهولة ويسر لكل أفراد

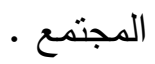
كل هذه الأشياء كان يمكن السيطرة عليها والإقلال من أضرارها إذا ما عولجت بطريقة إعلامية إيجابيه بدراسة الظروف والملابسات وتحديد أسبابها ودوافعها ونزع فتيل إستفحالها والعمل علي التخفيف من حدتها.

لذا فقد إهتم البحث بتعريف العنف والبحث عن أكثر من تعريف لتوضيحه من جهات إجتماعية وعلمية ونفسيه وأمنيه وثقافية والآثار المترتبة علي شيوع العنف وهي بالطبع آثار سلبية لا إيجابية.. ليس وراؤها خير 


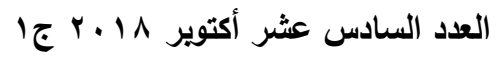

\section{المجلة العلمية لكلية التربية النوعية}

\section{Research summary}

\section{"The process of making the decision}

From the perspective of media foundation is that " the process of making the decision is very important and dangerous step in confronting crisis generally", as it requires a decision maker with definite features who has the skill and the ability of creating, renewing and applying the successful management techniques which guarantee achieving security and stability .

The process of containing crisis and controlling them requires finding the radical and successful solution which is represented in " taking the assertive and decisive decision quickly. The decision makers have to differentiate among the crises, the disaster and the problem, as the crisis is the most complicating and tangling one .

The crisis almost happen in an environment full of citizens and also the vital facilities, and they need an experience and courtesy to manage them and take the right decision for them, because any mistake could lead to explode another crisis, some of them are natural, human, economical or a political crisis too .

So, the decision makers have to define the type and the magnitude of the crises to put goals to achieve in containing it, and put another alternatives and scenarios to face the crises and control it . 
المقدمة:

تنقل إلينا الدراسات وأبحاث الخبراء والمتخصصين في مجال الإعلام الوقت الذي بدأ فيه

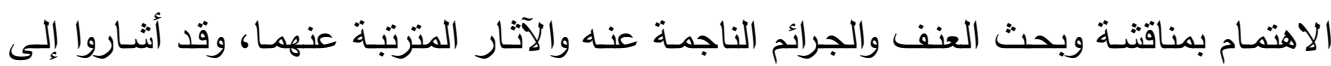

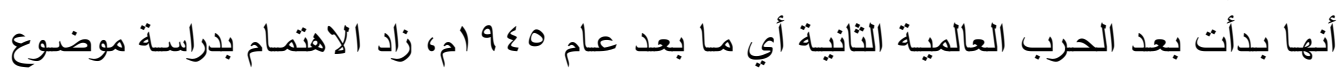
العنف، فقد لاحظ المهتمين والباحثين والخبراء في هذا الصدد ازدياد نسب الجرائم التي يشكائها

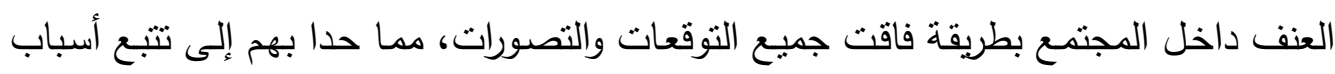

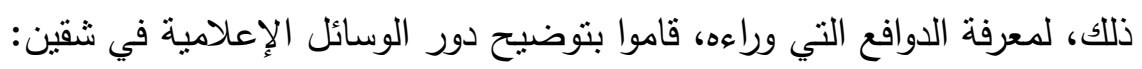

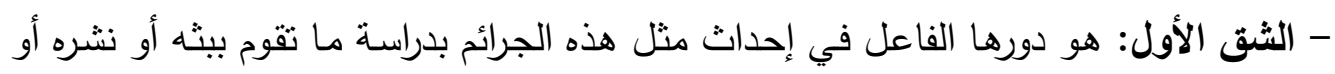

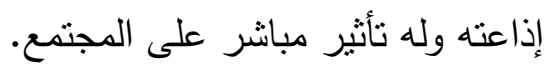
- الثق الثاني: هو دراسة دورها المؤثر فى مواجهة مثل هذه الجئه الجرائم والعمل على إيجاد طرق

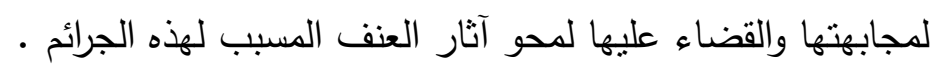

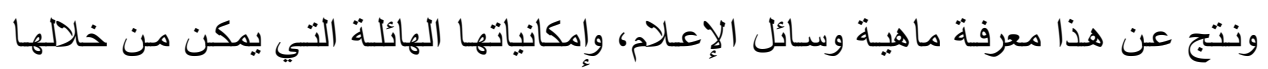

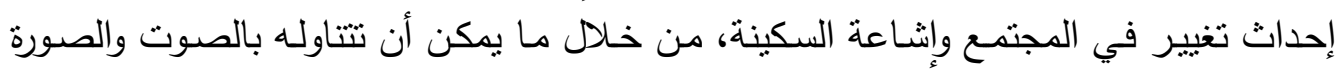
والكلمة المسموعة، وكذللك المقروءة التي تدعو لنبذ العنف والتمسك بالأخلاق والقيم.

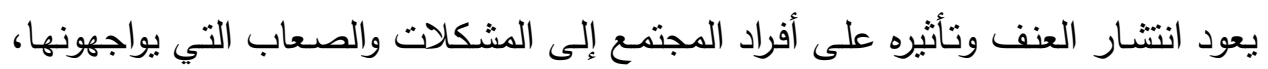

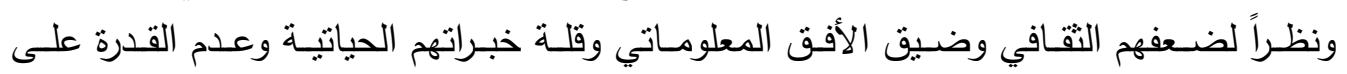

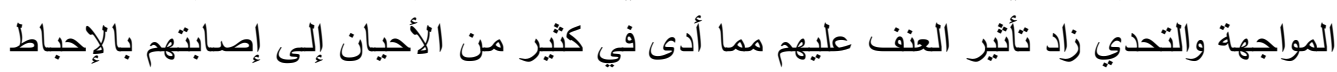

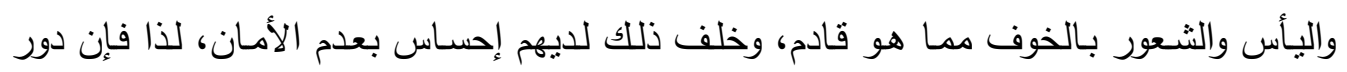

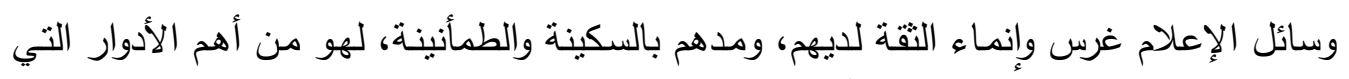
تؤديها أهم المؤسسات بالدول جميعاً.

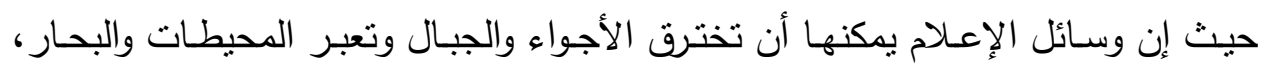

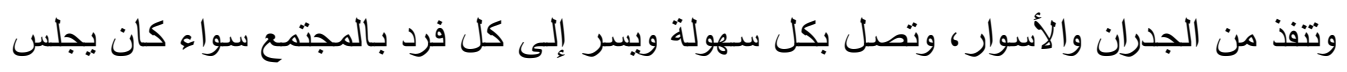

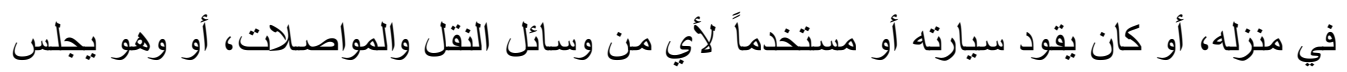

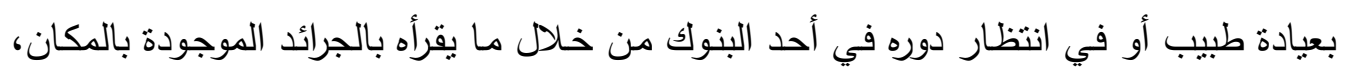
أو الإستماع إليها خلال الراديو أو مشاهدتها عبر التليفزيون والإنترنت.

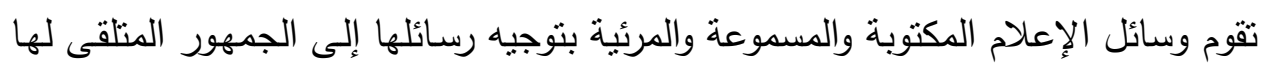

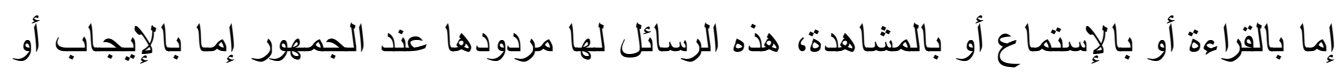

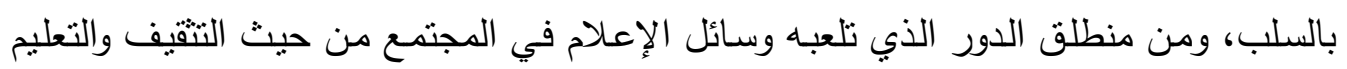

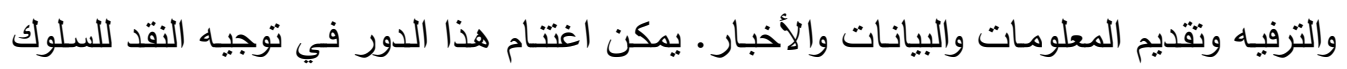

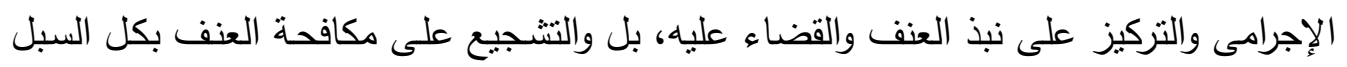


المتاحة والمشروعة من خلال الأقلام التي لها كل تقدير واحترام عند القارئ للصحف، والأعمال

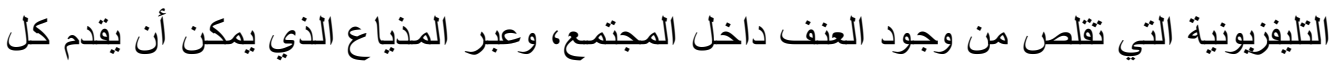

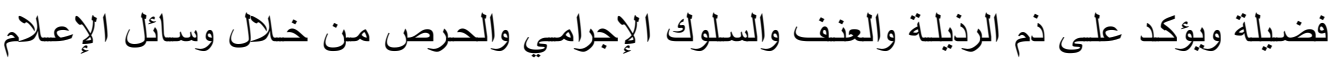
على مكافحة جرائم العنف والقضاء عليها. تتعدد جرائم العنف وتختلف أنواعها من مكان لآخر ومن مجتمـع لآخر ، وتتتوع أنتكاله

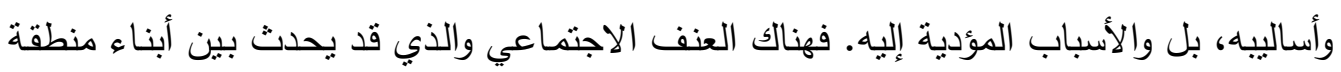

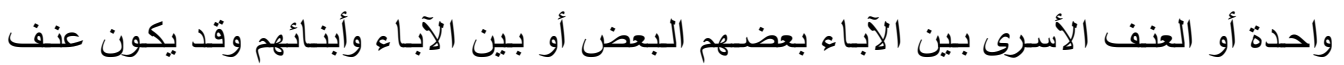

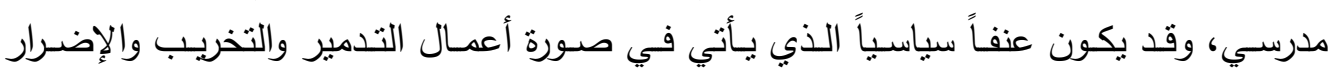

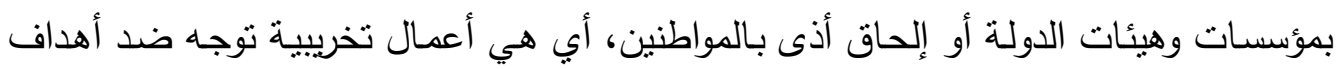

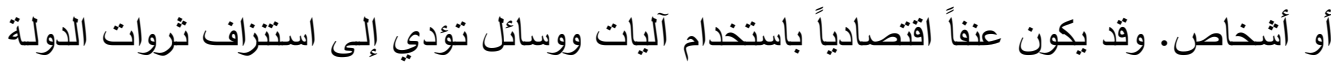

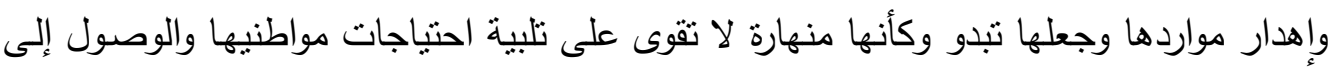

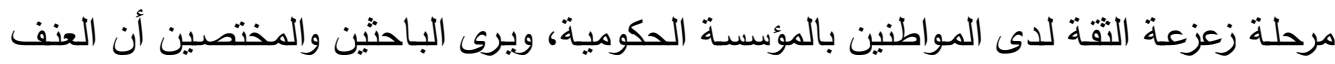

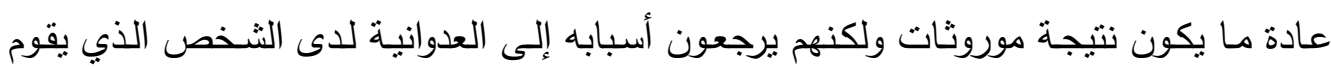
بعنف داخل المجتمع.

ويعد التليفزيون أهم وأقوى الوسائل الإعلاميـة التي تعمل على كثف العنف وذللك نظراً

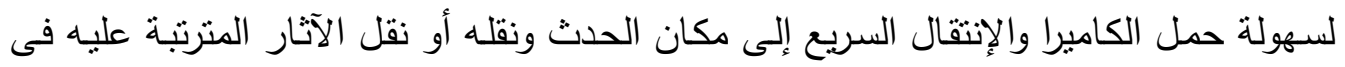

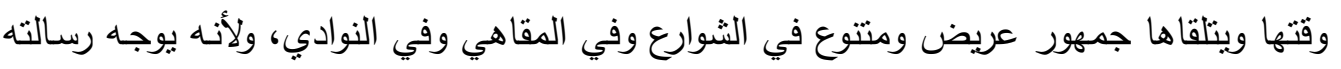

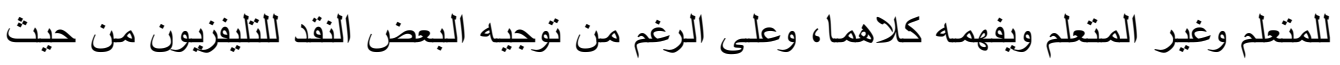

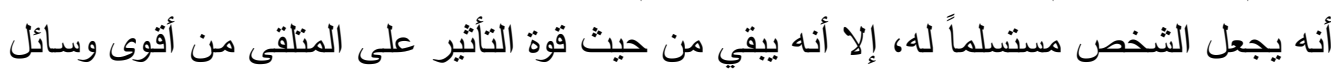

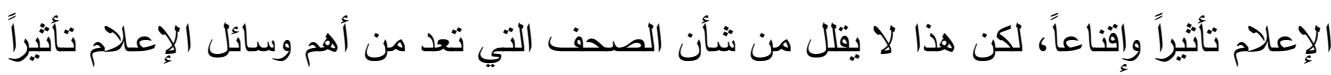

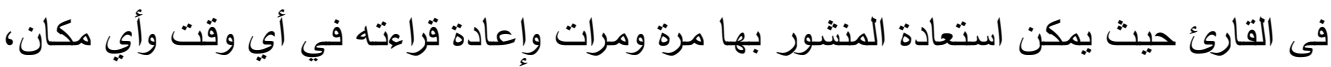

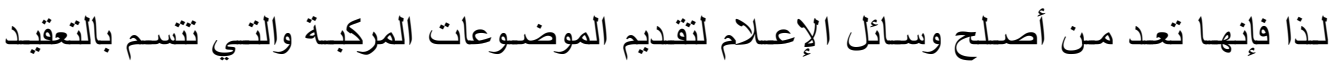

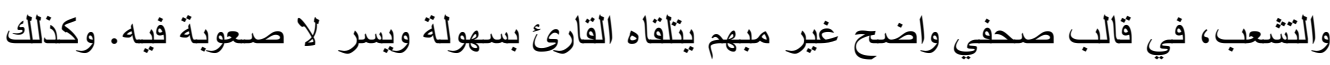
فإن الإذاعة هي الأخرى لها دورها وتأثيرها على جمهور المستمعين الذي يمكن أن ينلقاها وهو

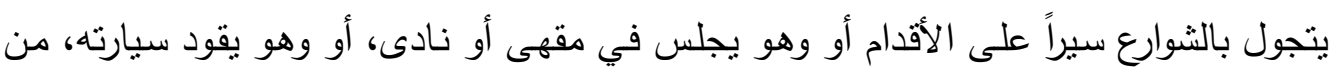

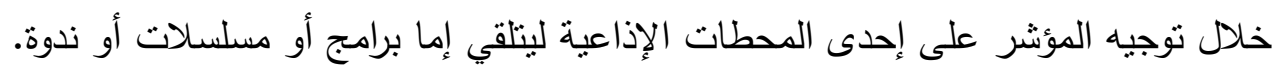

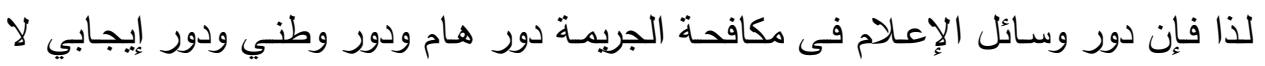

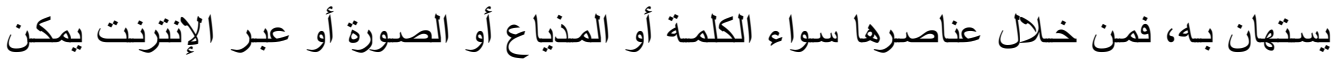

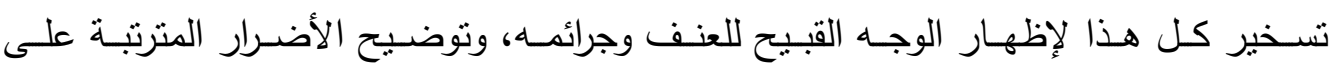
استخدامه، وإظهار الجانب المشرق في القضاء عليه والخلاص منها. 
تتنتـر الوسـائل الإعلاميـة عبر الفضـاء والأرض انتشـاراً واسـع المدى، وصـارت تحظىى

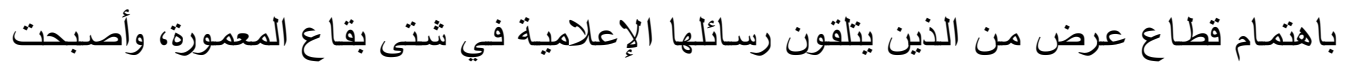

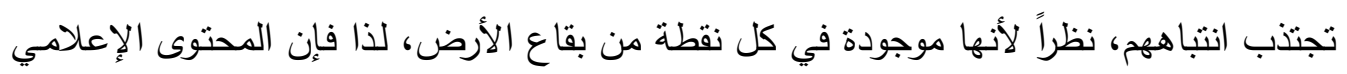

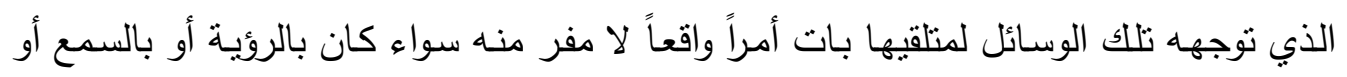
بالقراءة، ويقع المتلقى تحت تأثير هذا المحتوى المرسل إليه، ومـع زيادة موجة العنف والجرائم

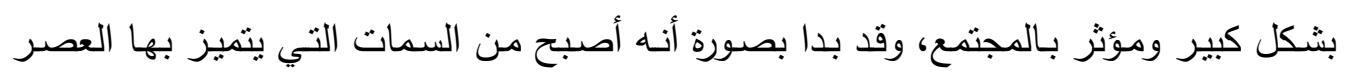

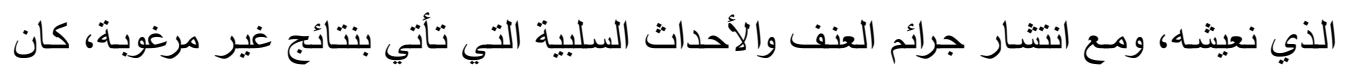

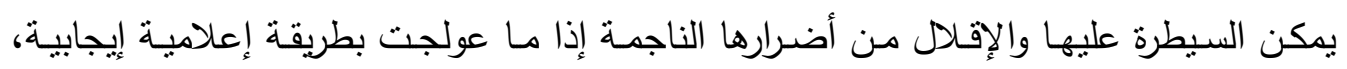

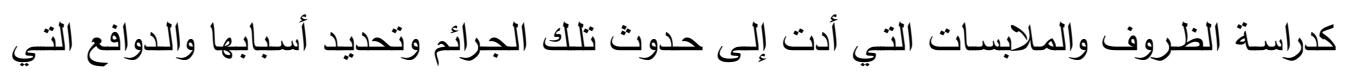

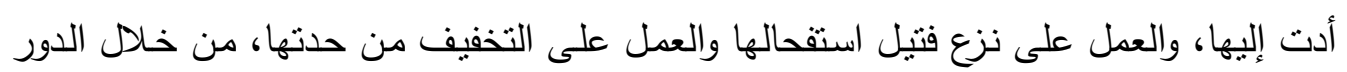

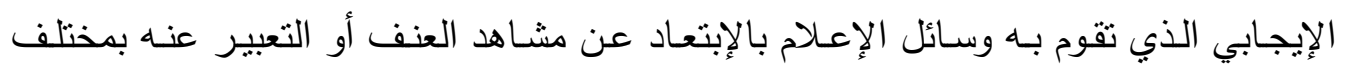

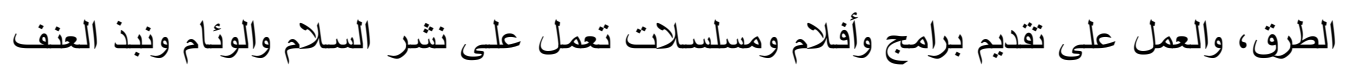

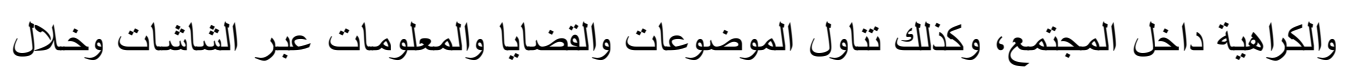

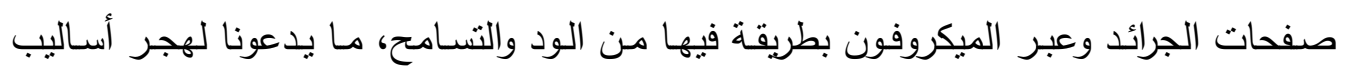

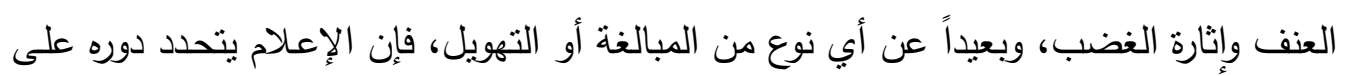

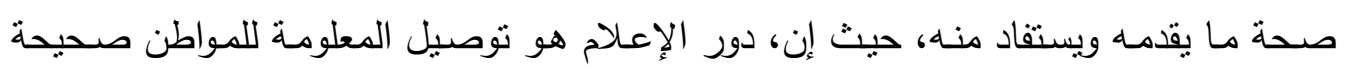

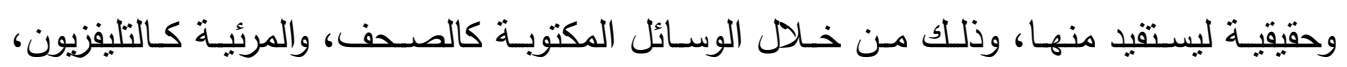

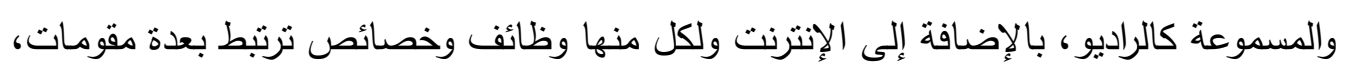

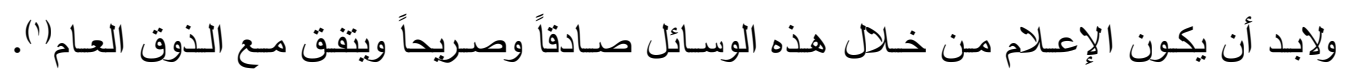

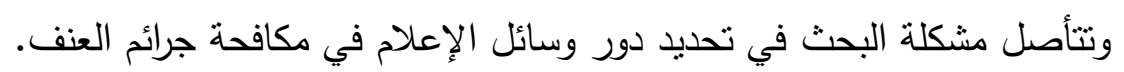

\section{أهمية البحث:}

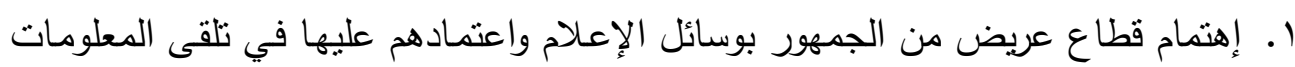

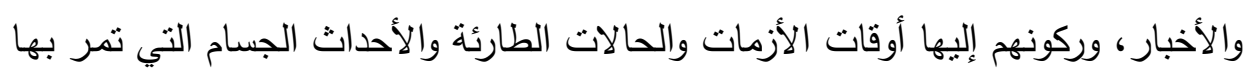

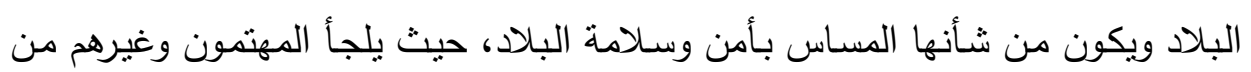

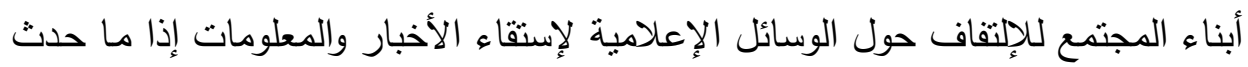

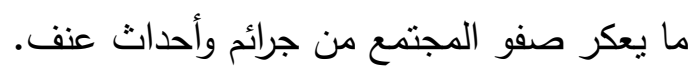




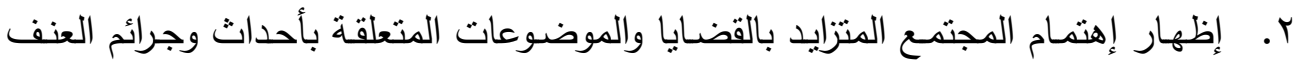

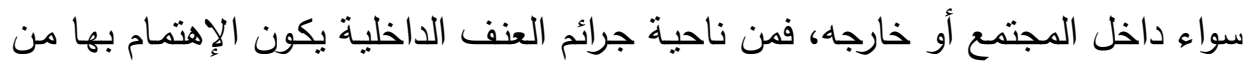

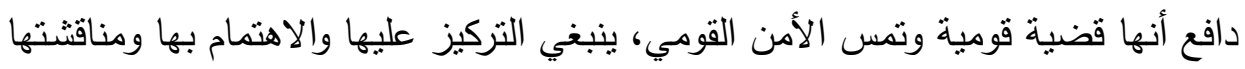

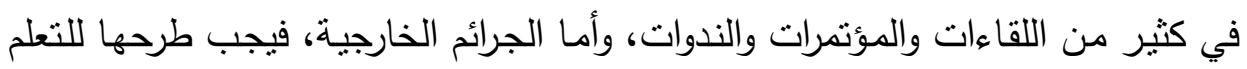

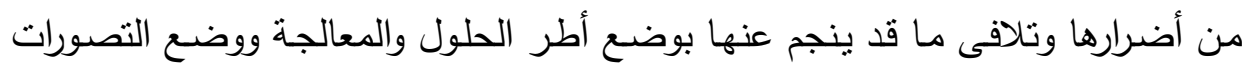
والمقترحات التي تؤدي إلى عدم حدوثها عندان التها.

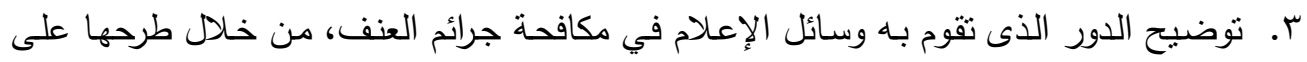

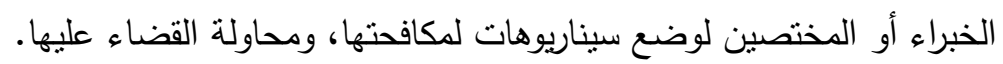

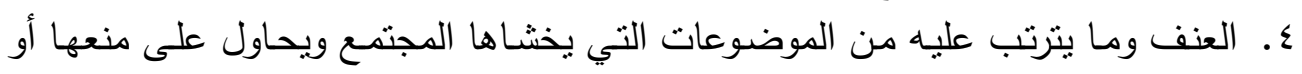

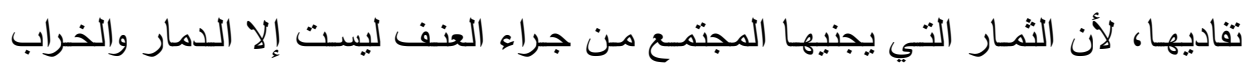

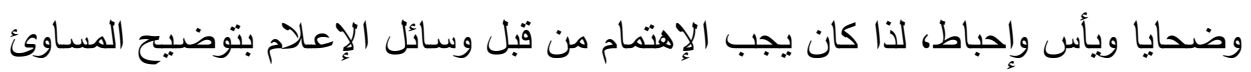

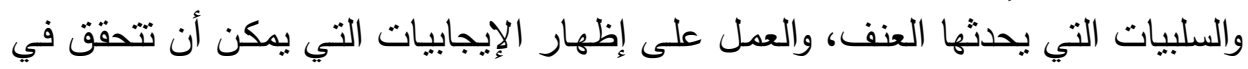
حال التصدي له وقهره والقضاء عليه.

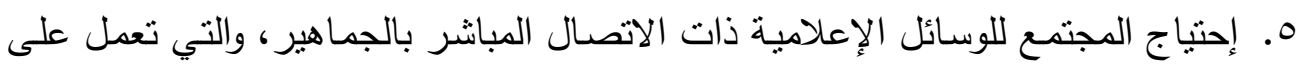

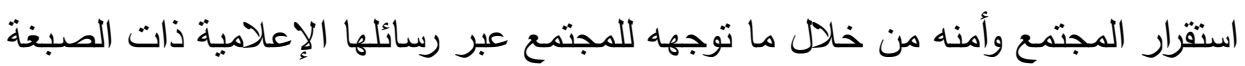

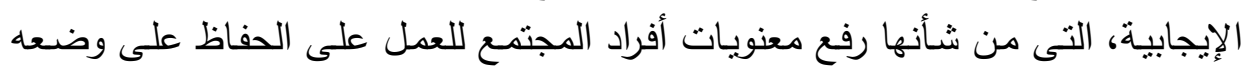

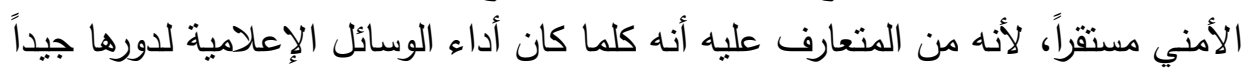

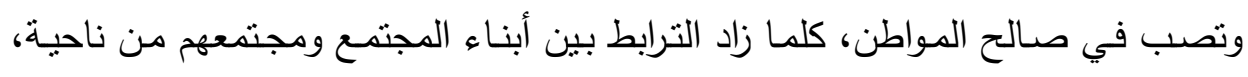
ومن ناحية أخرى إزدياد إرتباطهم بوسائل إعلام مجتمعهم.

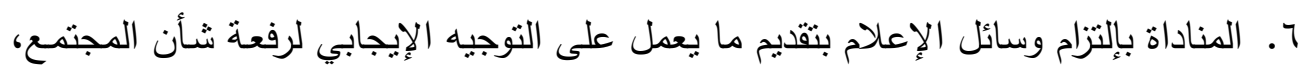

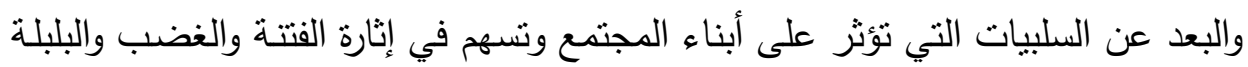
بينهم وتؤدي إلى حدوث جرائم عنف. أهداف البحث:

يسعى البحث إلى إبراز أهمية دور وسائل الإعلام في مكافحة جرائم العنف، ويتفرع هذا الهدف الرئيسي إلى عدة أهداف فرعية منها:

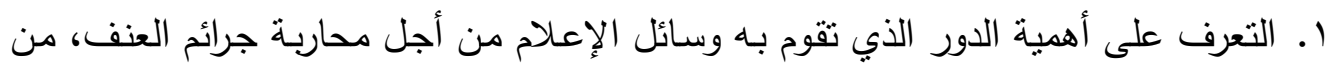

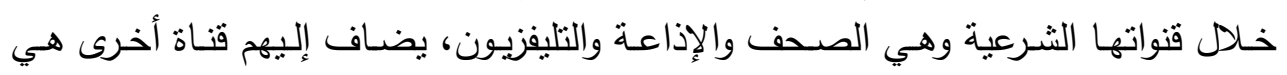
شبكة المعلومات الدولية، بغرض إظهار الدور الذبي تضطلع بـهـ أجهزة ووسـائل الإعـلام

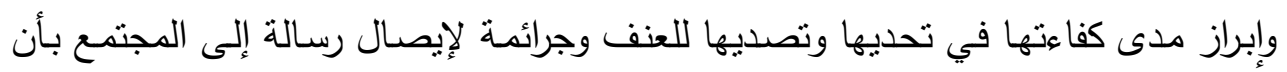

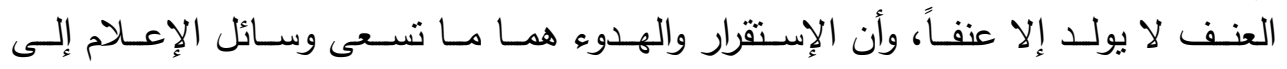




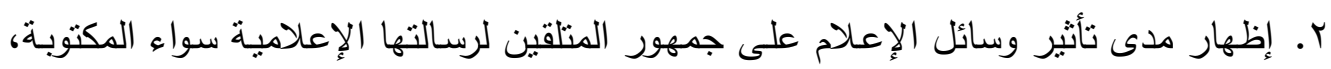

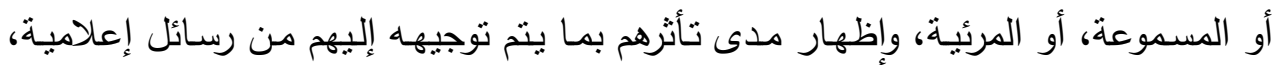

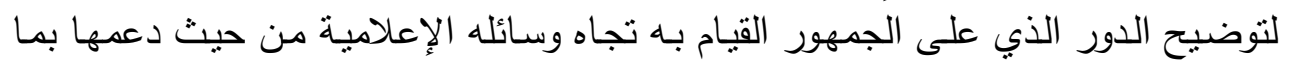

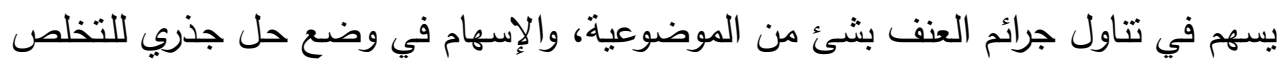

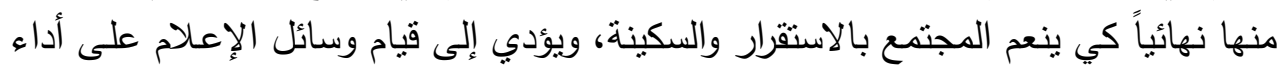

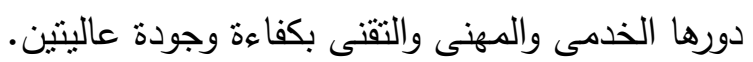

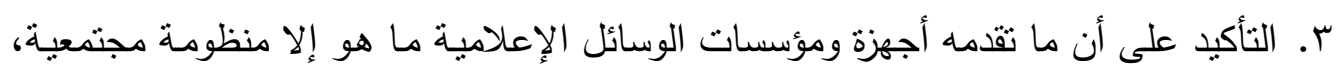

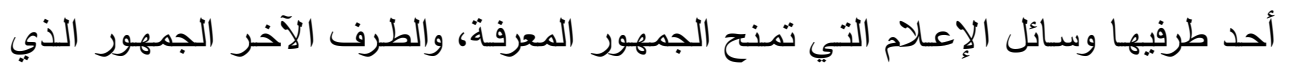

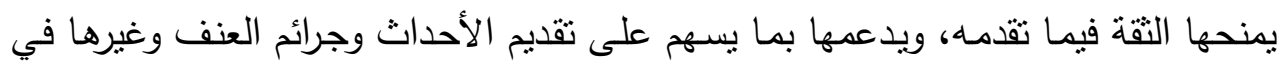
قالب من المصداقية.

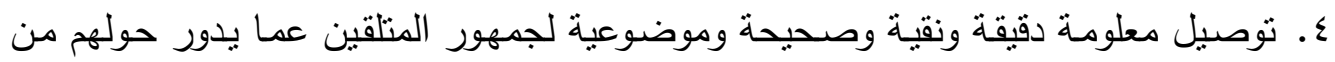

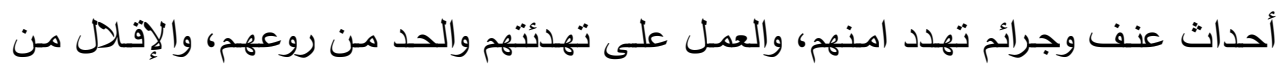

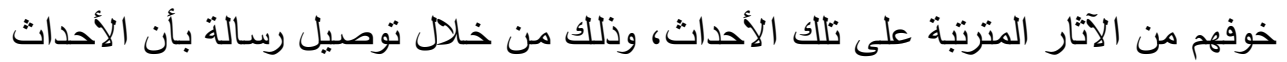

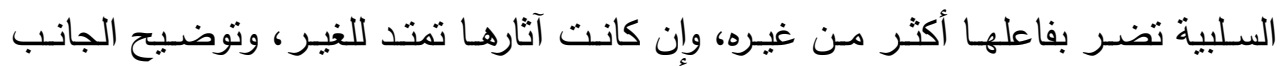

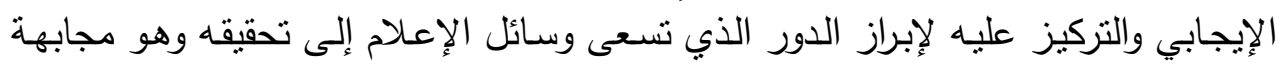
ومحاربة جرائم العنف.

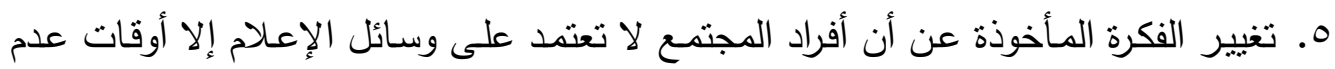

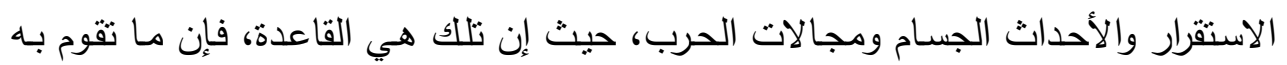

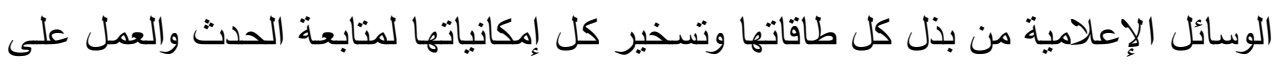

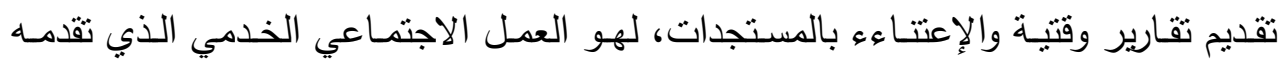

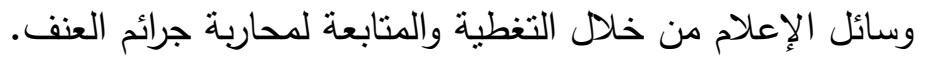
منهج البحث:

يستخدم البحـث المـنهج الوصـفي الذي يعتمـد على الإطـلاع على الدراسـات المرتبطـة

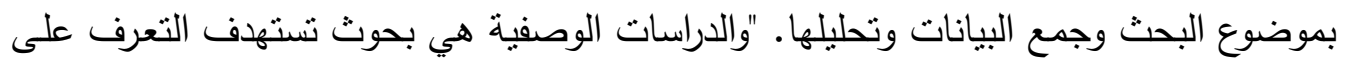

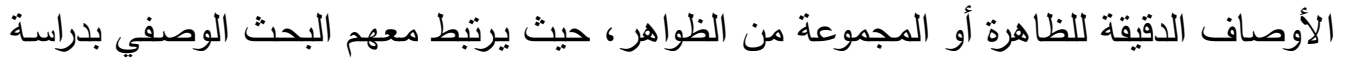

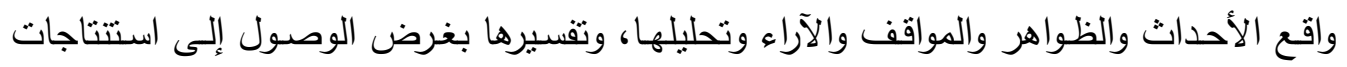

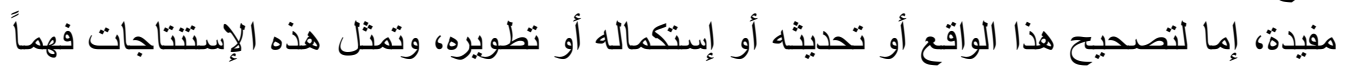

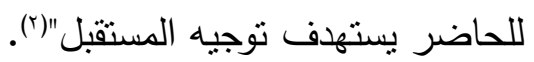

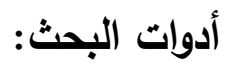

يستخدم البحث العديد من الأدوات البحثية الأساسية منها: المؤلفات العلمية ذات الصلة بموضوع البحث، البحوث والدراسات والرسائل العلمية، شبكة المعلومات الدولية (الإنترنت). 


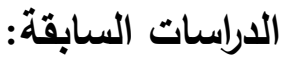

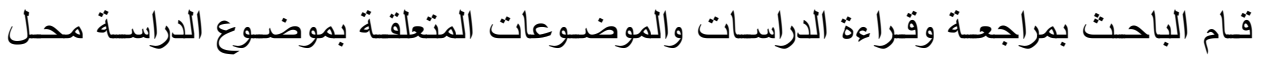

$$
\text { البحث، أو التى تشير إلبها من قريب أو بعيد. }
$$

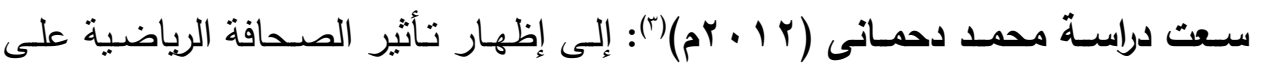

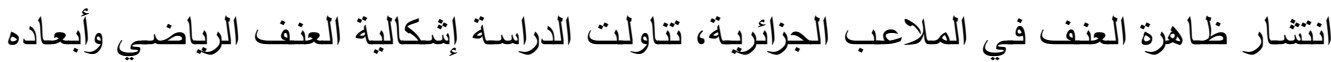

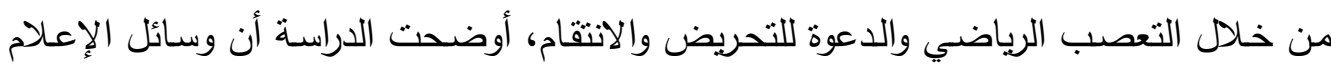

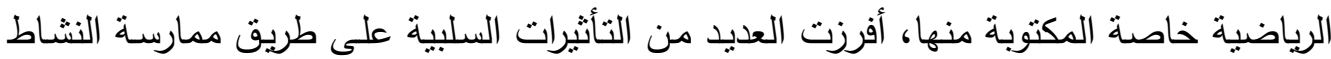

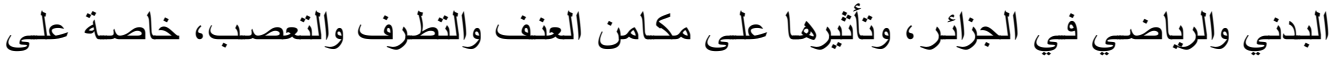

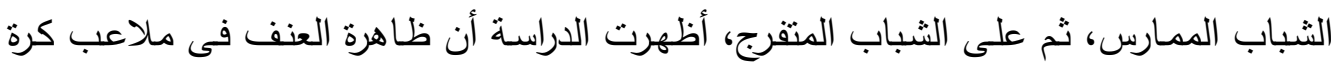

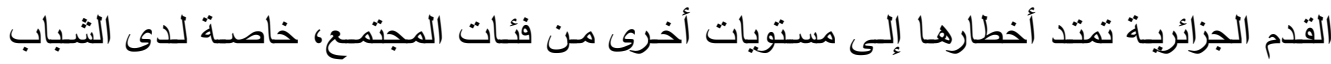

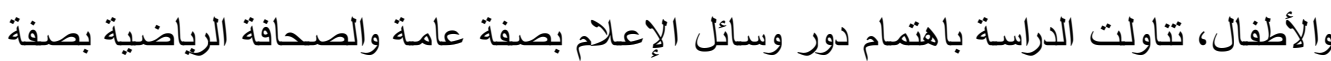

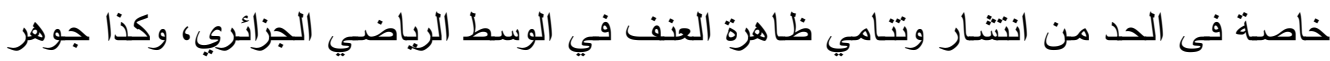

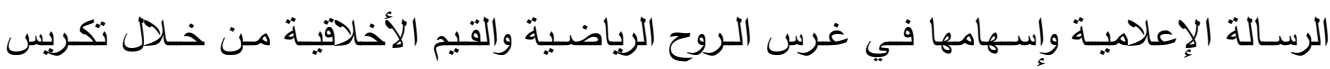

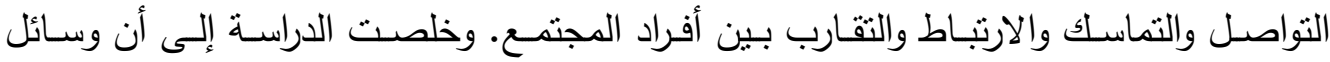

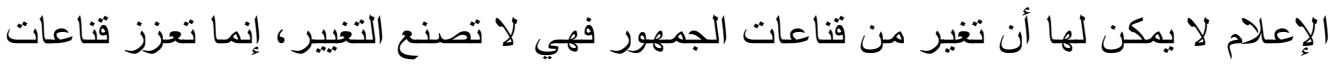

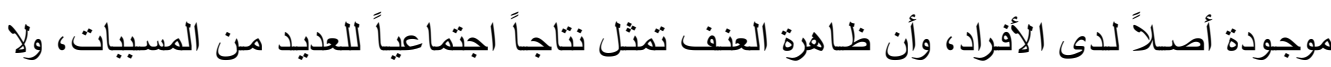
يمكن لحلها الإكتفاء بمسئولية الصحافة الرياضية فقط. وسعت دراسة هدى بنت يوسف الصعيب (r l • rم) (؛): إلى توضيح دور وسائل الإعلام

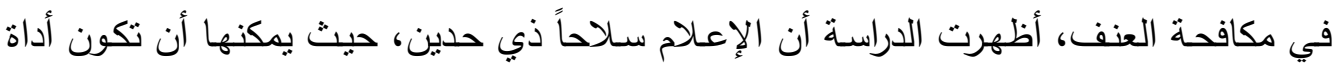

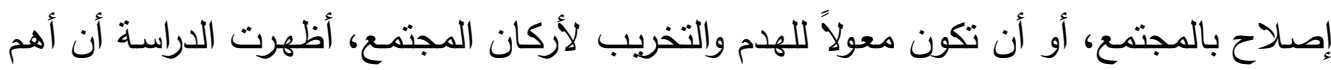

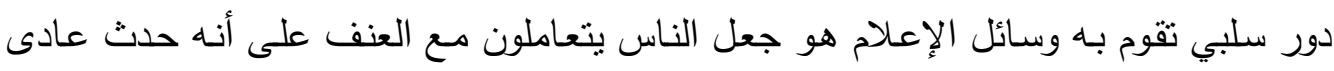

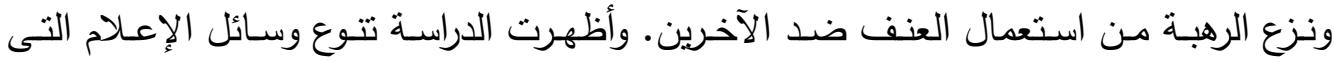
تساعد على إنتقال العنف بسهولة بين الناس وكذا انتشاره ومنها: الفيس بوك، والتويتر ، والهاتق

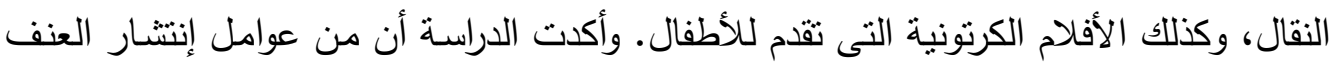

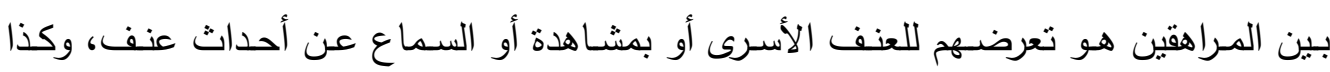

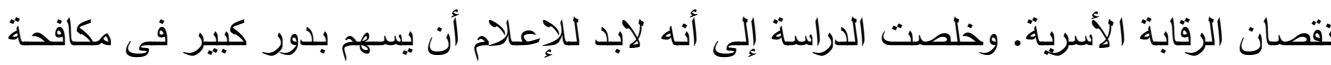

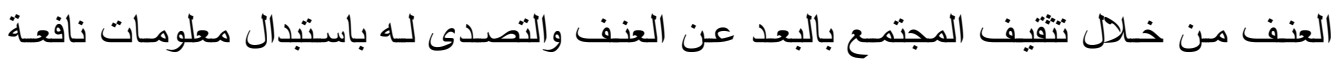

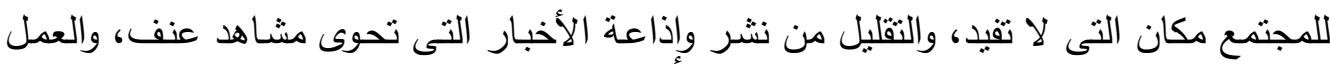

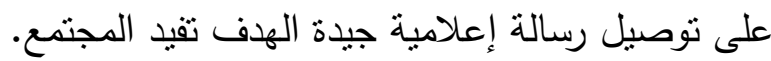




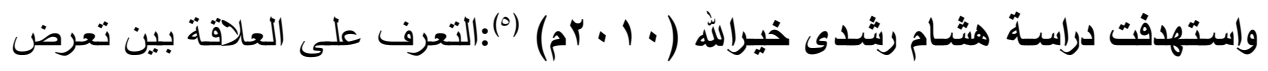
الثباب الجامعى لأحداث العنف السياسى فى الصحف والتليفزيون وقلق المستقبل لديهم من خـلال التعرف على دوافعهم لتعرضهم لأحداث العنف، والتعرف على أكثر وسـائل إعلاميـة

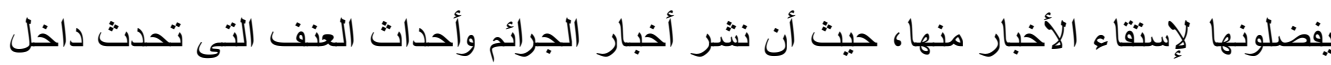

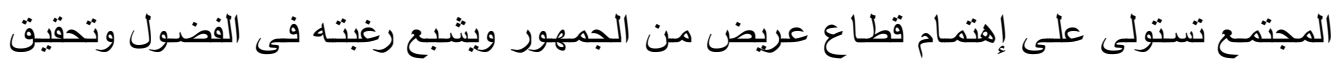

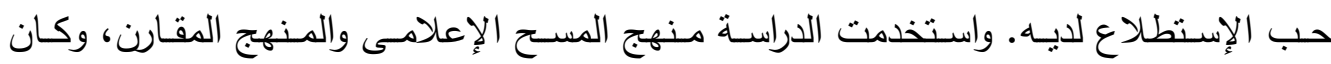

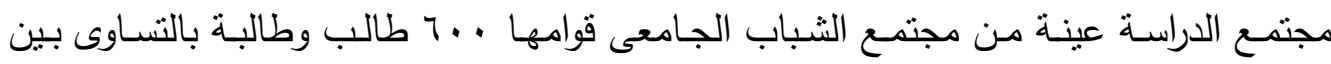
جامعات (المنوفية- المنيا- عين شمس)، بواقع . r مبحوث لكل جامعة مقسمين إلى إناث

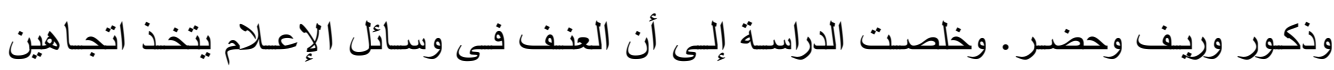

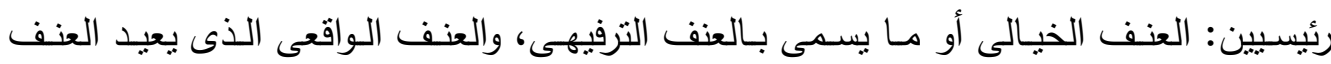

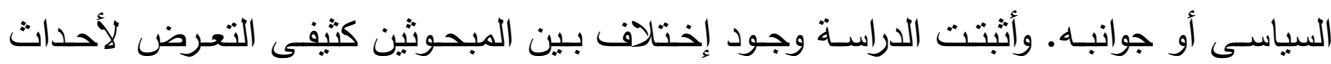
العنف فى كل من الصحف والتلافزيون وبين متوسطى التعرض لهما.

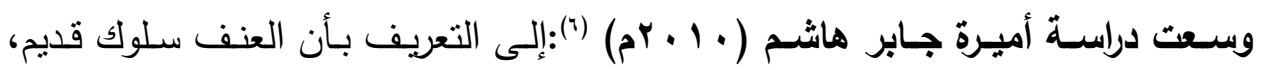
تتاولت الدراسة مجتمع الثباب الجامعى بالعراق، وهدفت إلى معرفة أثر برنامج ارشادى وقائى

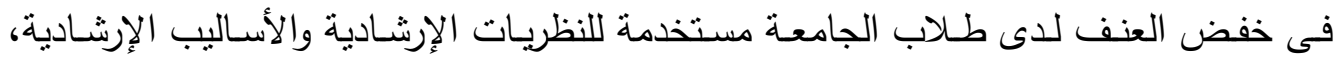

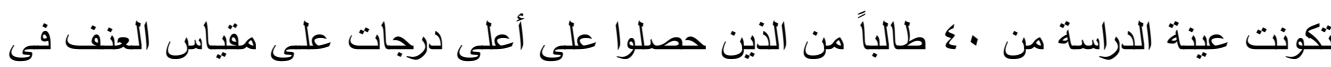

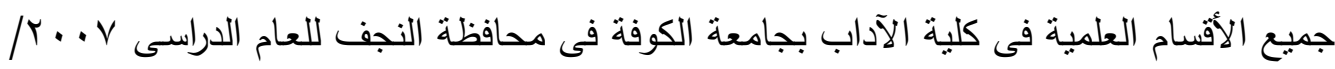
1 . . rم. واستخدمت الدراسة استمارة الإستبيان ومنهج المسح، وهدفت الدراسة اختبار الفرضية التى تتير إلى أنه لا توجد فروق ذات دلالة احصائية بين متوسط طلاب المجموعة التجريبية ومتوسط درجات المجموعة الضابطة على مقياس العنف فى الإختبار البعدى. وخلصت الدراسة

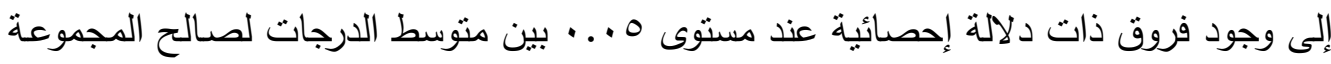

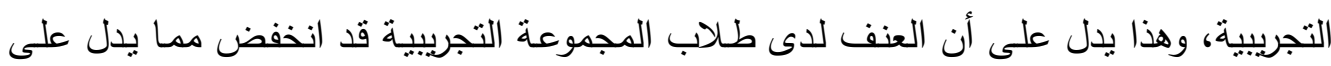
أن البرنامج قد أثز فى خفض السلوك وأثبت نجاحه.

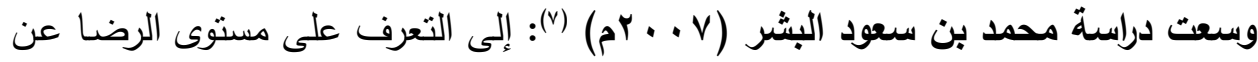

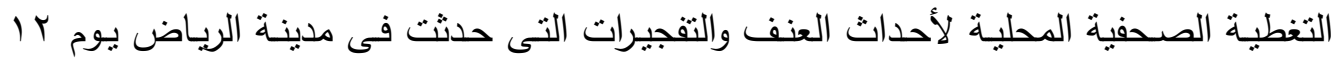

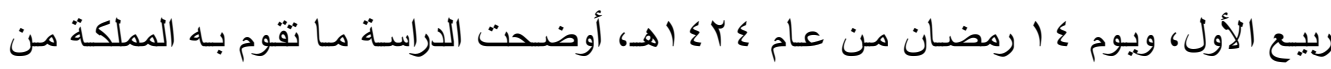

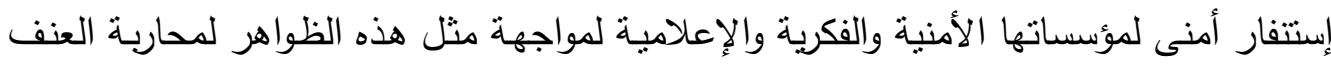


والقضاء عليه، من خلال تكاتف جميع الأجهزة من أجل الحفاظ على أمن وسلامة المجتمع.

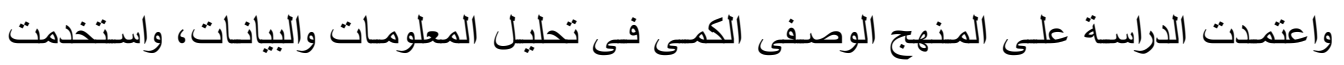

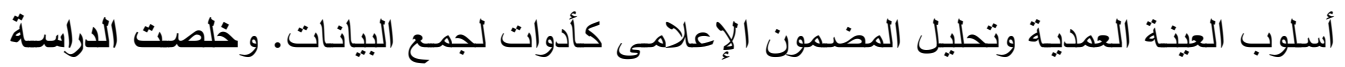

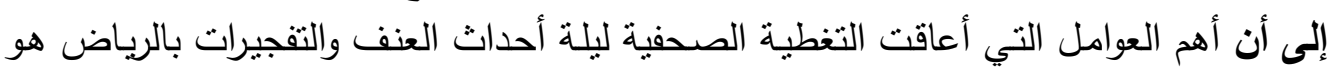

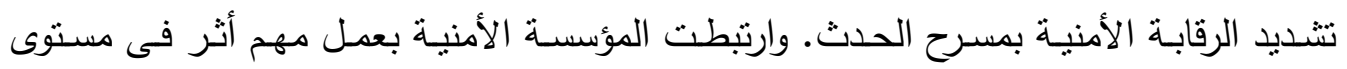

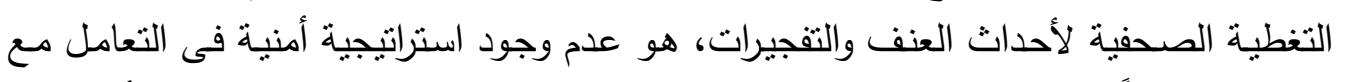

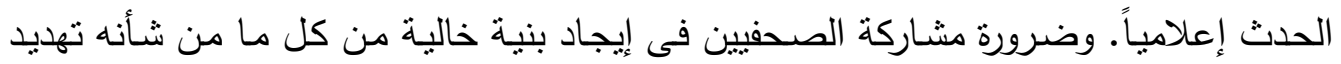

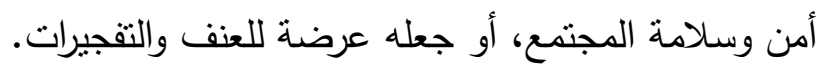

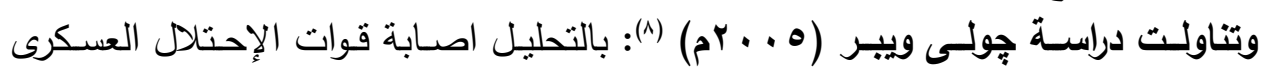

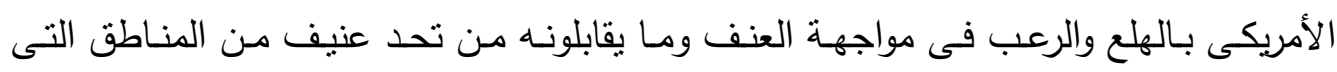

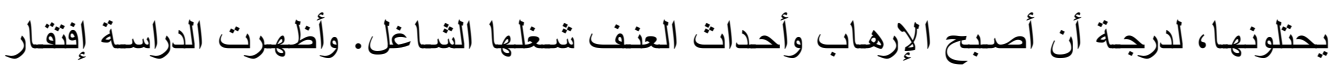

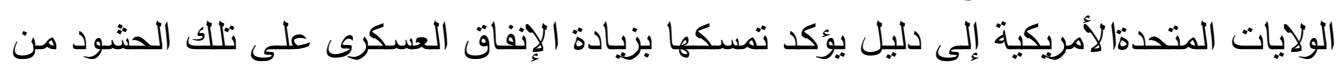

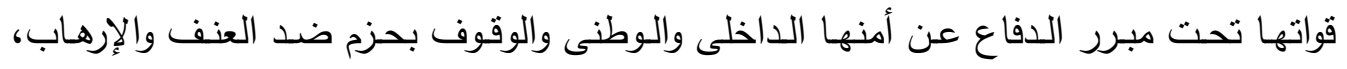

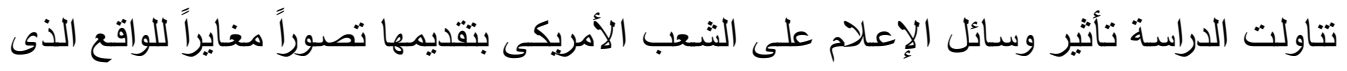

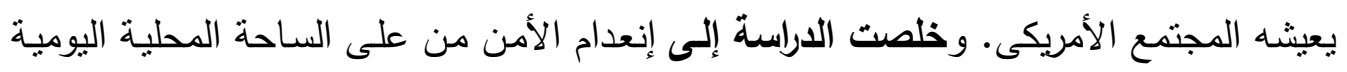

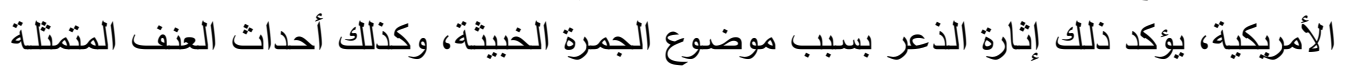

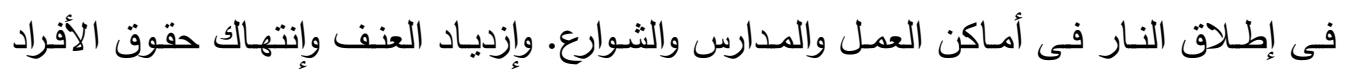

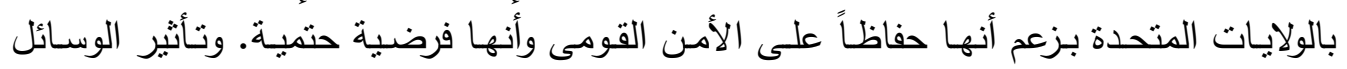

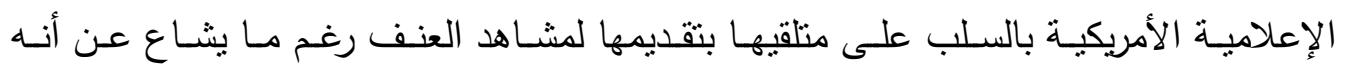
لأمن الأولة.

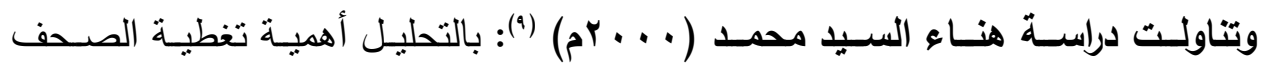

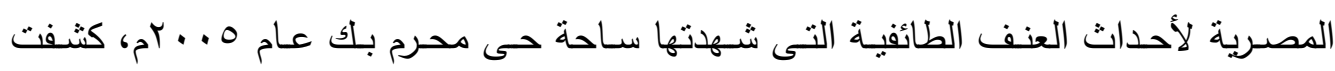

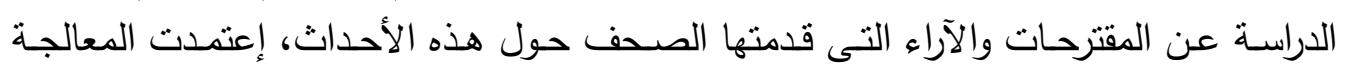

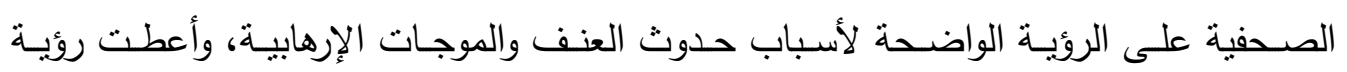

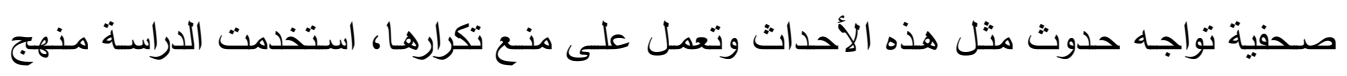

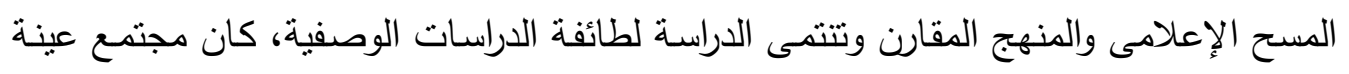

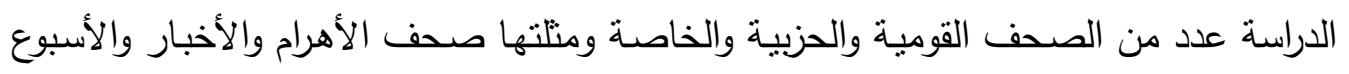

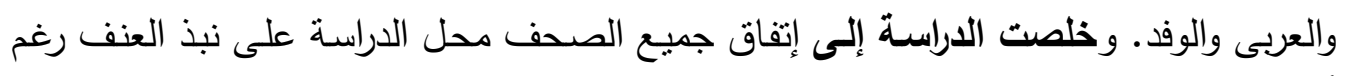

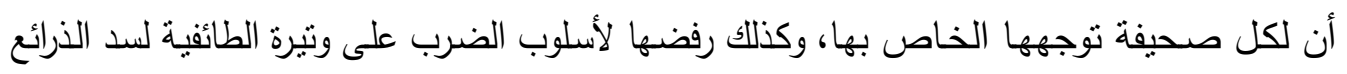

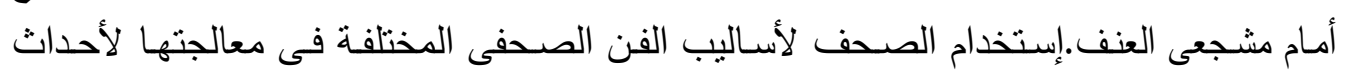
العنف، ومناداتها بإيجاد حل لعبور الأزمة ومكافحة العنف والقضاء عليه. 


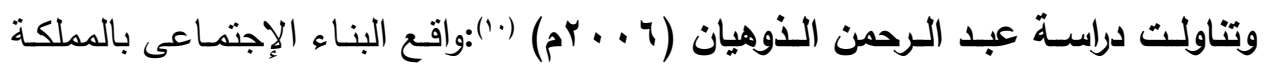

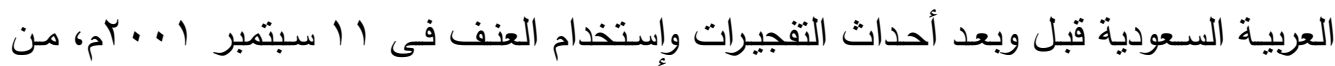
خلال المؤسسات التلبفزيونية الإخبارية، وتوضيح علاقة ذللك بالأمن القومى للمملكة، وأثره عليه

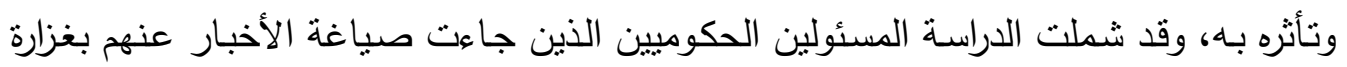

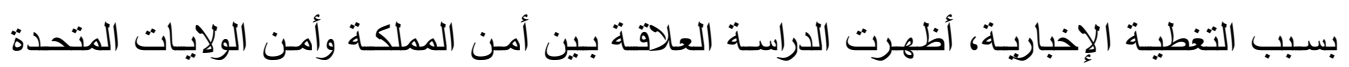

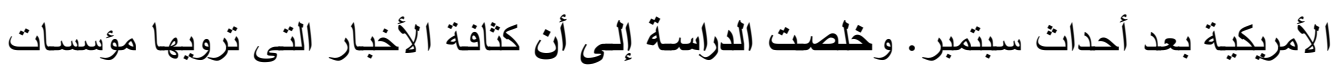

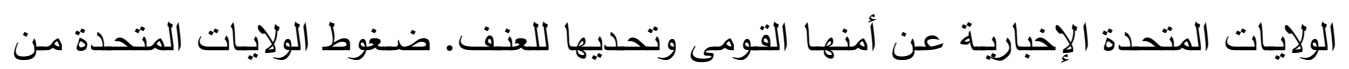

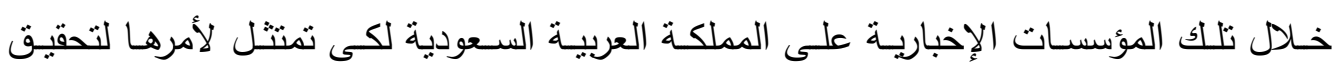

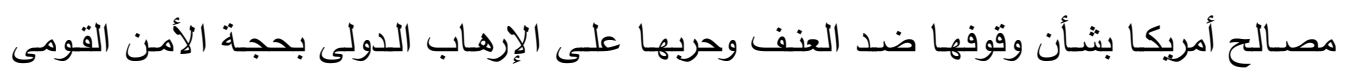
للملكة العربية السعودية. واستهرفت دراسة سباركس ( • 99 (1) (1'):التعرف على إتجاهات مشاهدى أحداث العنف

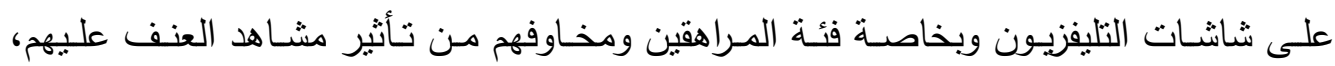

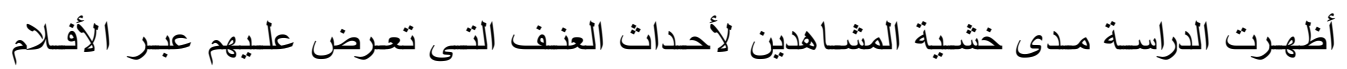

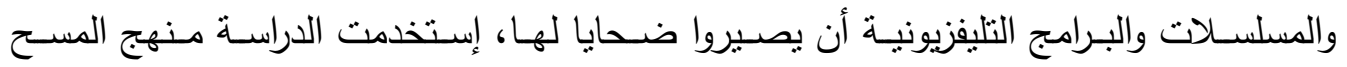

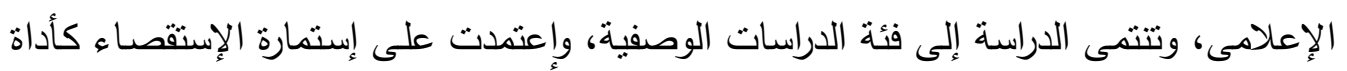

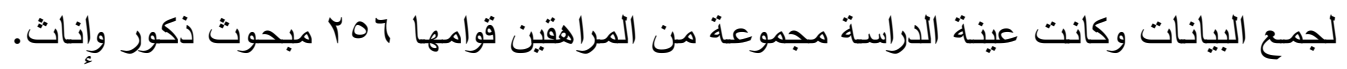

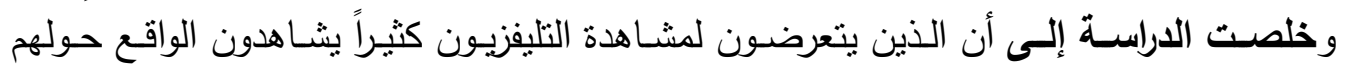

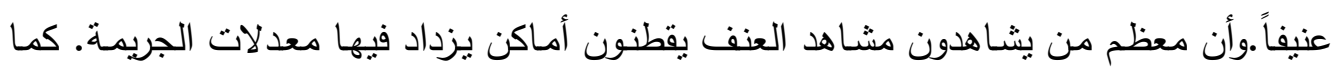

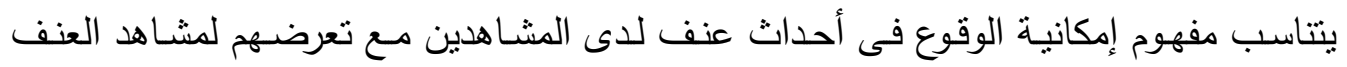
بصفة مستمرة تتتاسب طردياً، بمعنى وجود ترابط وتماسك بينه إنها. التعليق على الدراسات السابقة:

إهتمت بعض الدراسات بالتعرف على العلاقة بين التعرض للعنف والمستوى الاقتصادي

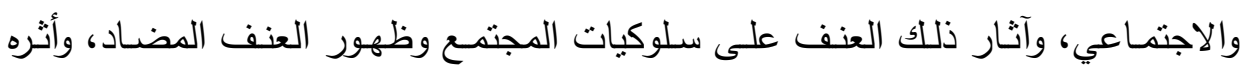
على العلاقات الأسرية والتشنئة. أظهرت الدراسات أن الذين تعرضوا لممارسة أى نوع من أنواع العنف عليهم يكون نسبة إندماجهم وإنخراطهم مع المجتمع ضعيفة. أوضحت الدراسة أهمية وسائل الإعلام ودورها المؤثر فى خفض الخف العنف، وأنه نوجد ندرة فى الدراسات التى نتتاول موضوع العنف.

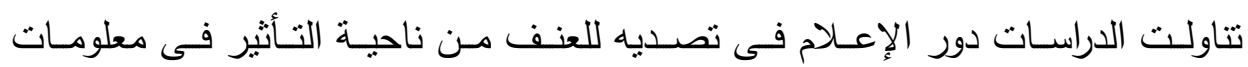
وإتجاهات الجمهور نحو موضوع العنف. 


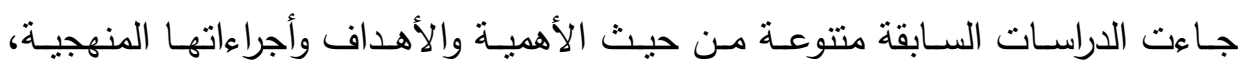
وجاءت معظمها من الدراسات الوصفية التى استفاد منها الباحث.

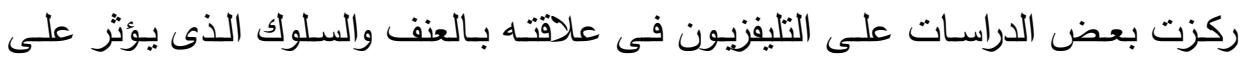

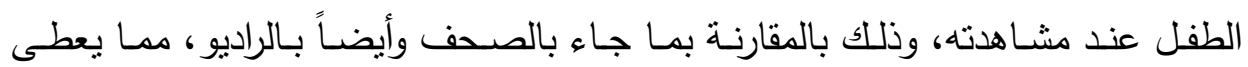

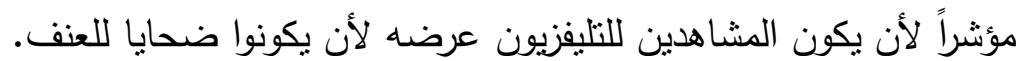

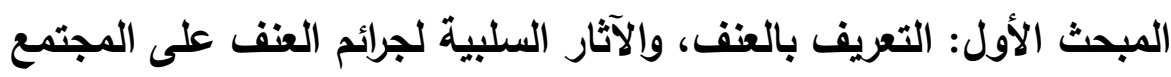
وقسم الباحث المبحث إلى مطلبين: المطلب الأول: التعريف بالعنف:

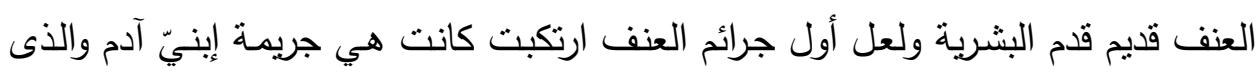
قتل أحدهما الآخر بسبب سلوك عدواني، وحقد أضمرته نفسه ضد شقيقه فارتكب حماقته وقام بإطاعة نفسه التي أمرته بأن يقابل أخيه بكل عنف وعدوانية فهب عليه فقتله، ولعل ما بعد ذلك الك

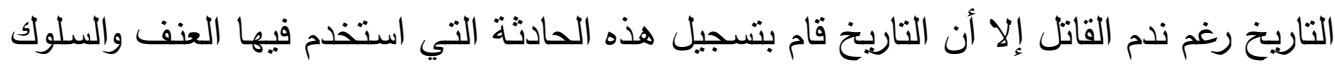

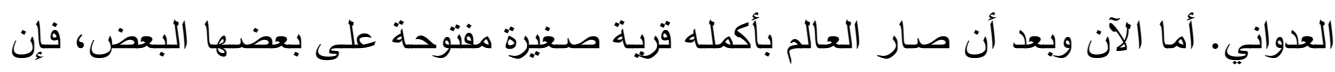

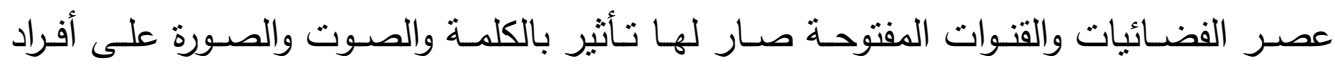

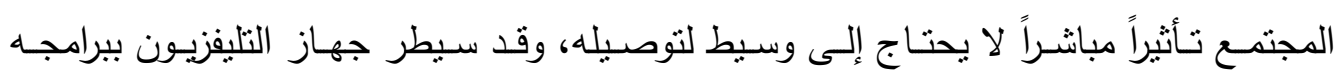
ومنوعاته وكذلك شبكة المعلومات الدولية والتى تعمل على نشر صحافة إلكترونية عبر رسائلها

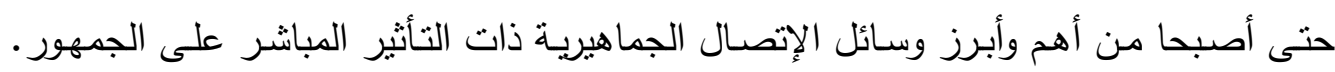

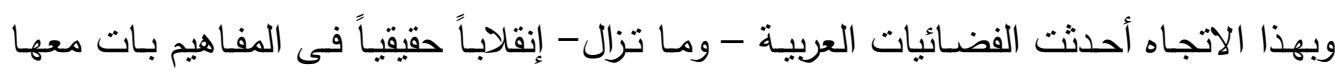
المسـقبل مفتوحـاً على تحديات كثيـرة وكبيـرة، ومسع تطـور تكنولوجيـا العلـوم وعلدوم الإعـلام والإتصال، أصبحت الصورة التليفزيونية هى سيدة التعبير ومالكة النظر والسمع والانتباه والفكر ولئر

$$
\text { تعريف العنف: الواعي واللاواعي(r'). }
$$

وقد قام جورج جاربنر مـع فصيل من أصدقائه المختصين أثناء مشـاركتهم البعض فى في

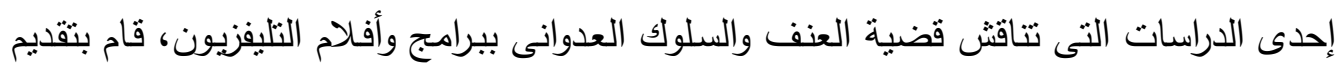

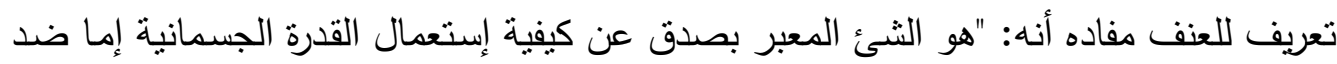

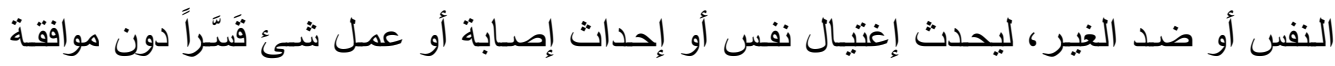

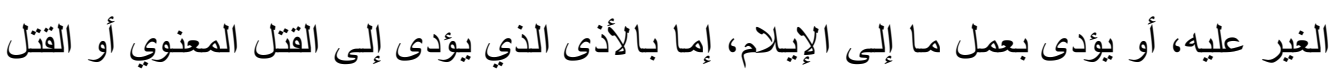

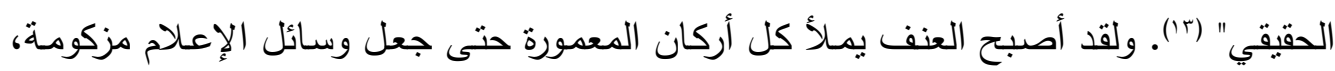


فلا تخلو صحيفة أو نشرة أخبار بالإذاعة أو بالتليفزيون، بل وعبر الإنترنت إلا ويوجد أحداث

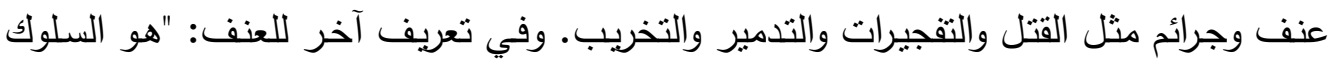

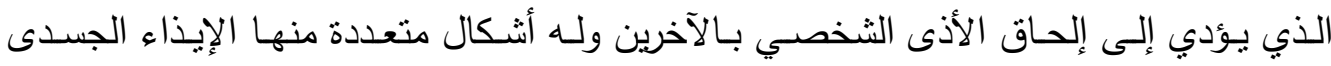

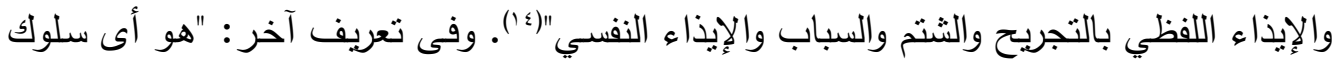

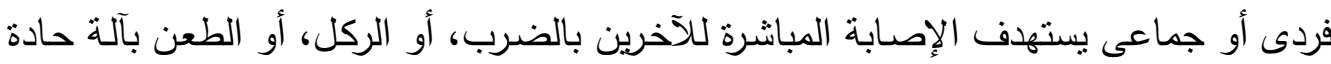

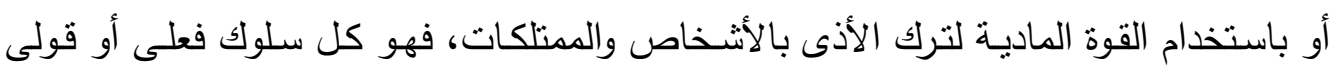

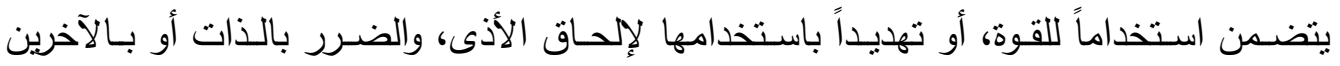

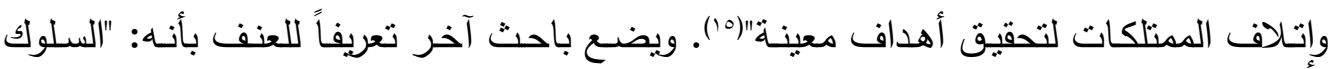

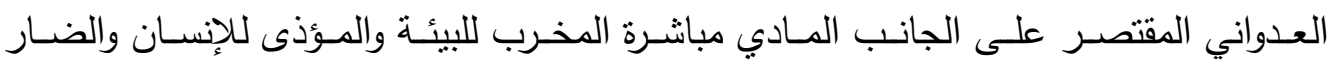

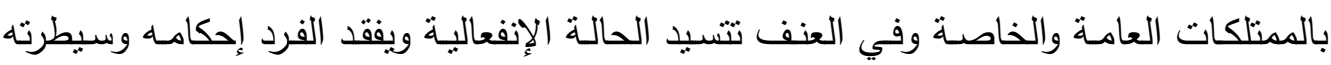

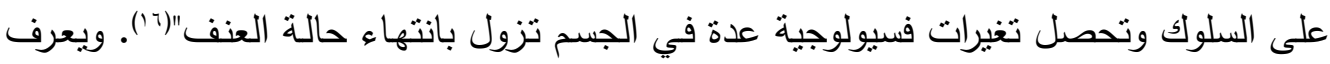

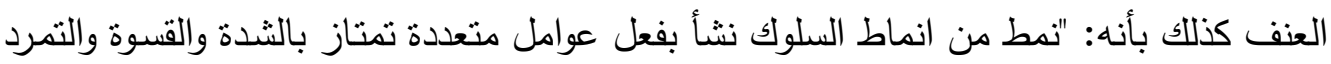

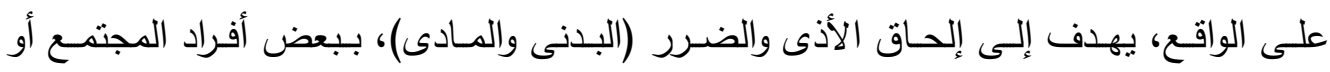

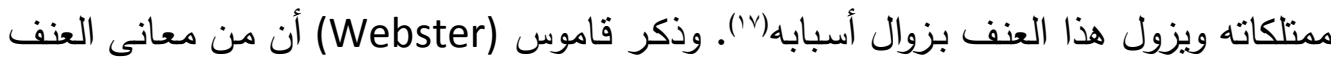

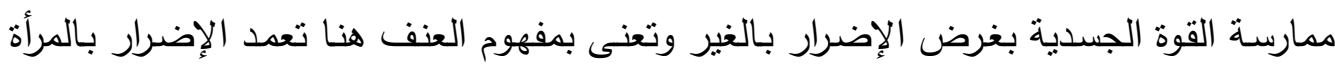

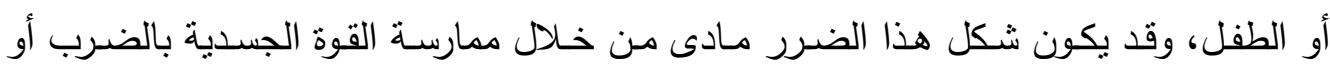

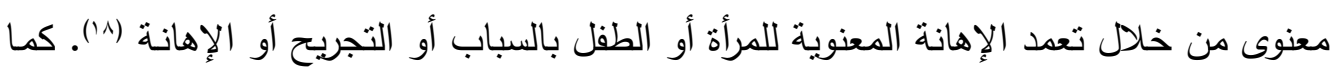

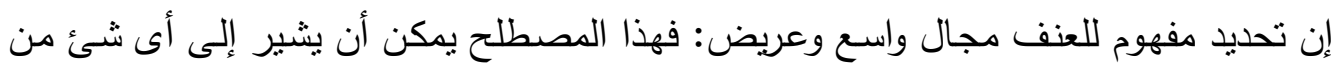

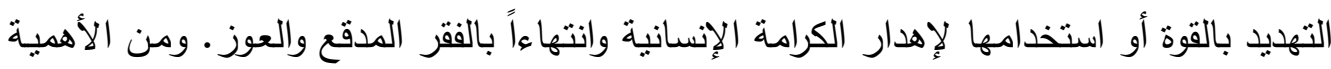

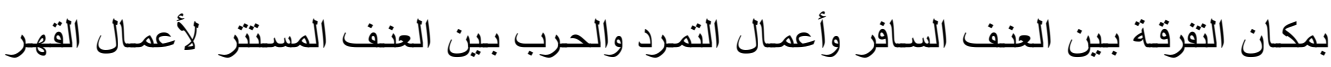

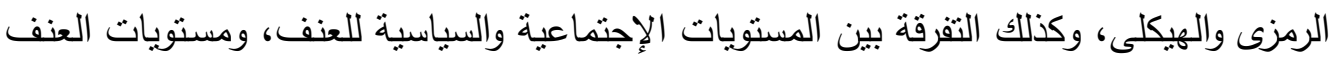
فيما بين الأفراد (19).

ويرى الباحث أن العنف يندرج تحت السـوك الفردى أو الجمـاعى الذى يصـاحبه نزعـة

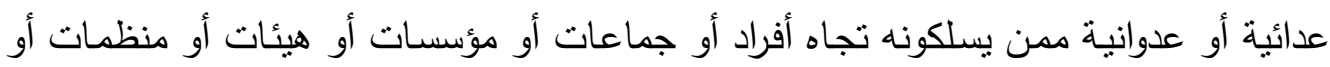

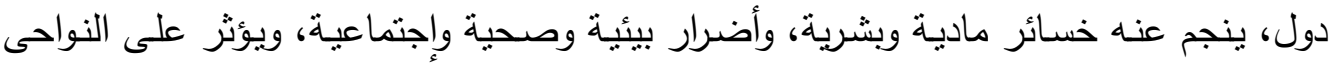

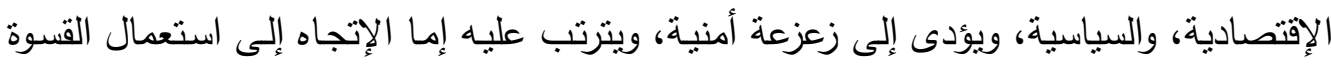

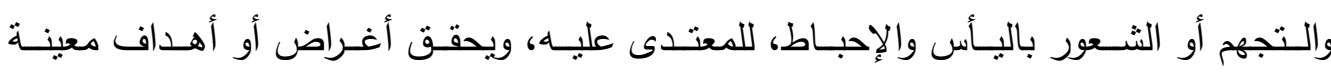
لمستخدمه، ويستمر باستمرار العامل المؤثر على وجوده، وينتهى بالتخلص من العامل المؤثز عليه، أو لزواله من تلقاء نفسه، أو القضاء علئهراء لعليه 
المطلب الثاني: الآثار السلبية لجرائم العنف على المجتمع:

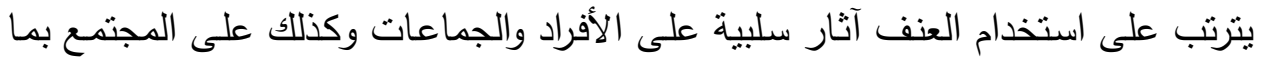

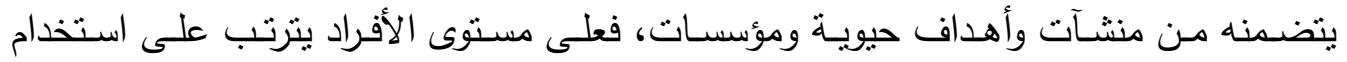

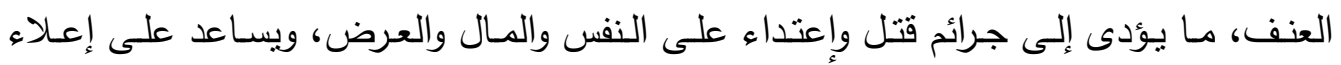

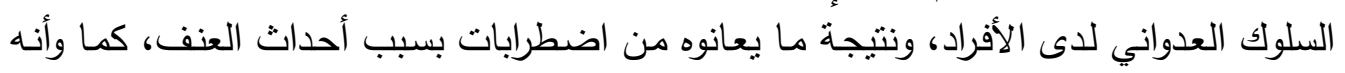

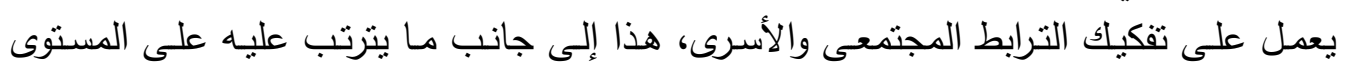

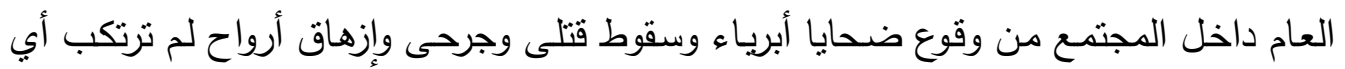

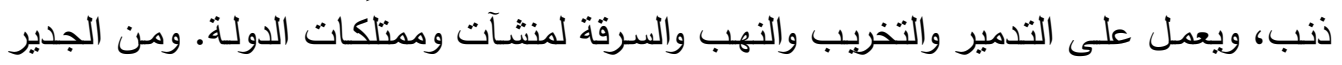

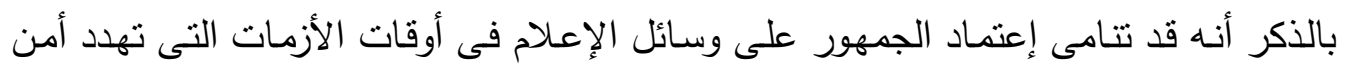

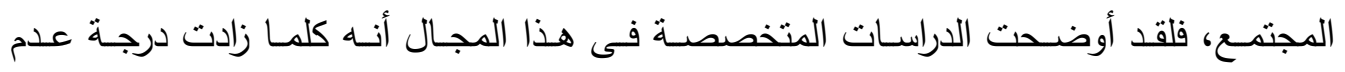

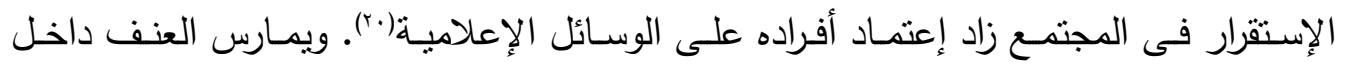
المجتمع على الفئة الأضعف دائماً وتكون دائماً هى الضى الضحية (الأطفال / المرأة).

$$
\begin{aligned}
& \text { - - العنف ضد الأطفال. } \\
& \text { - - }
\end{aligned}
$$

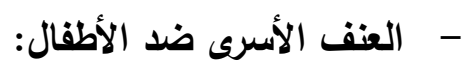

- - يعرف العنف ضـ الأطفـال: بأنه إلحاق الأذى والضـرر الجسدى بالطفل من قبل

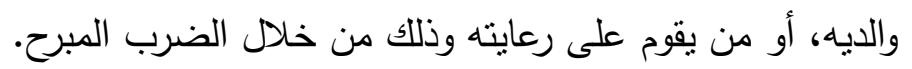

- مظاهر العنف الأسرى الموجه ضد ضل الأطفال:

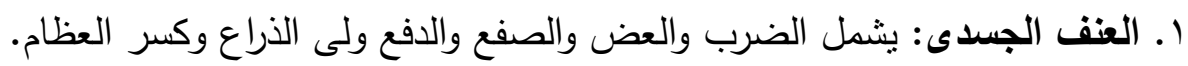

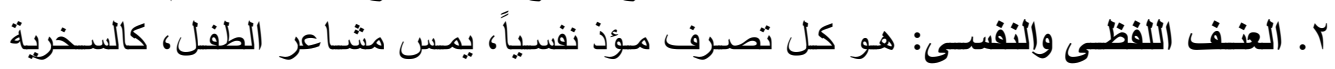

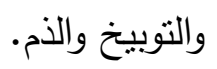

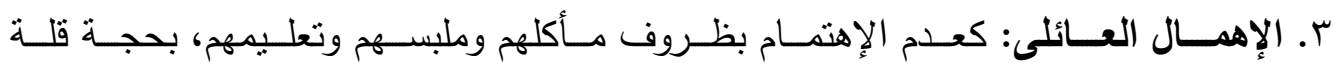

$$
\text { الموارد المالية. }
$$

ـ. الإعتداء الجنسى: ويعد الإغنصاب أخطر صور الإعتداء الجنسى فى نظام الأسرة ويكون تحت التهديد غالباً.

ه. إجبار الطقل على العمل: مجرد تشغيل الطفل لساعات طويلة وإرهاقه بما يفوق طاقته يعتبر

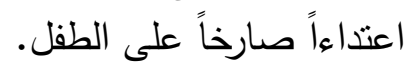

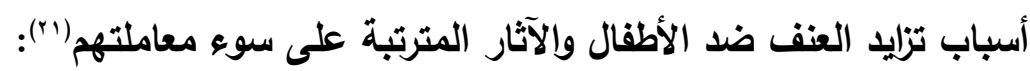
- أسباب تزايد العنف ضد الأطفال: • أسباب اقتصادية: مثل تزايد معدلات الفقر والبطالة. أسباب إجتماعيية: مثل التفكل الأسرى والخلافات الزورجية. 
المفاهيم الخاطئة حول أساليب التتشئة بافتراض استخدام قدر من العقاب الجسدى.

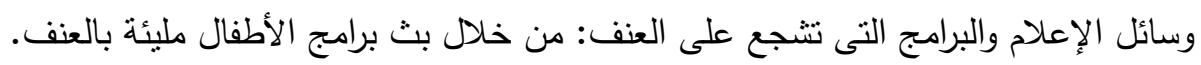

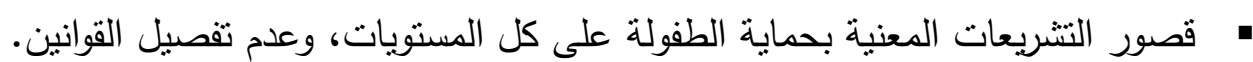
- الآثار المترتبة على سوء معاملة الطفل:

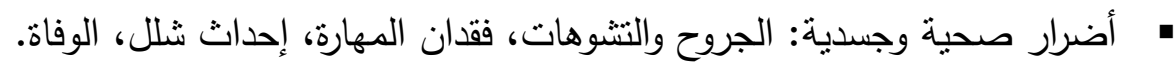

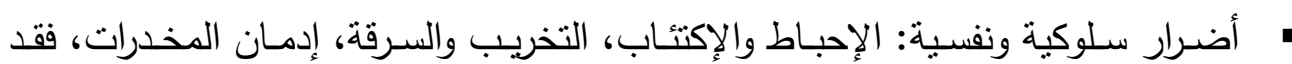
الثقة بالنفس. • أضرار إجتماعية: صعوبة التواصل مـع الآخرين، الحقد والكراهية للمجنمع، تولد العنف لديه. ويمكن عن طريق وسائل الإعلام ودورها فى المجتمع ومالها من تأثثر فى نفوس المتلقين

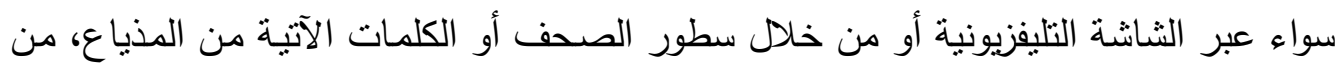

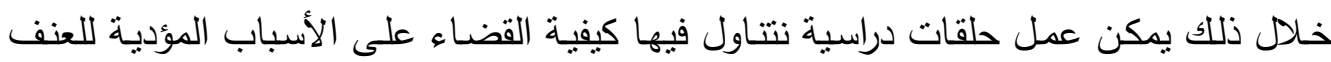
ضد الأطفال والتخفيف من حدة الآثار المترتبة على سوء معاملة الأطفال، والعمل على العلى إزالتها

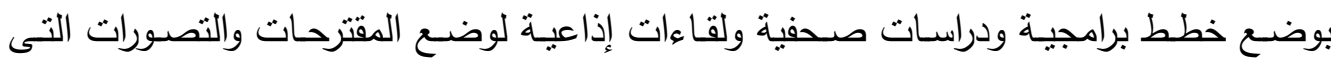

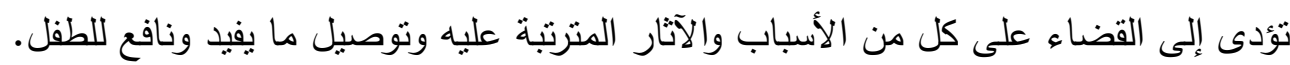

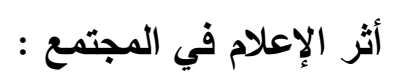

ويتمنل أثز الإعلام في المجتمع من خلال: العدوان اللفظي: الذى يظهر عبر الإكتار من الأصـوات العاليـة والضـيجيج والصياح الغاضب، والثتائم المتكررة، والتهديد بالكلام والإشارات.

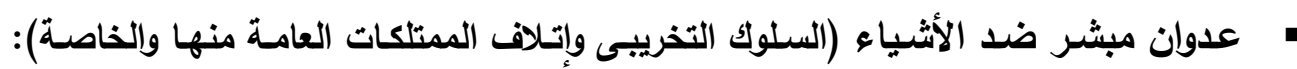

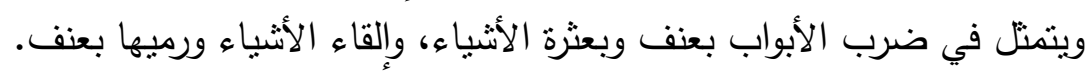

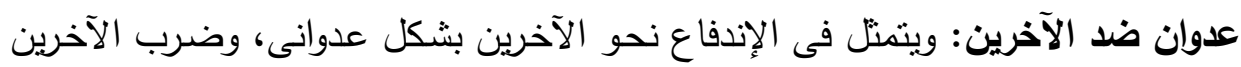

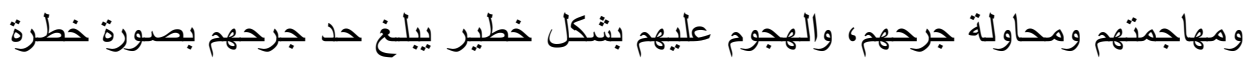

ولقد ذهب العديد من العلماء المهتمين بدراسة الصحة النفسية وعلم النفس إلى أن ما يقدم

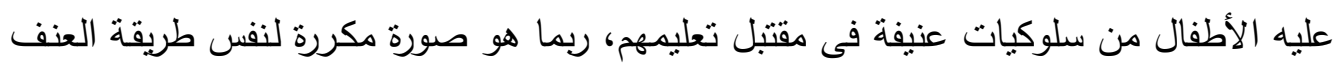

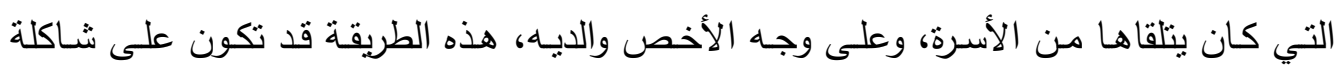

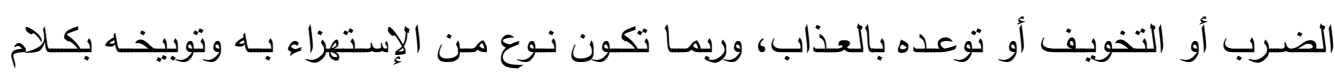


العدد السادس عشر أكتوير 1 | • ب ج1

المجلة العلمية لكلية التربية النوعية

ويمكن تفسير مشاهد العنف والسلوك العدوانى الذى تتقله وسائل الإعلام من خلال:

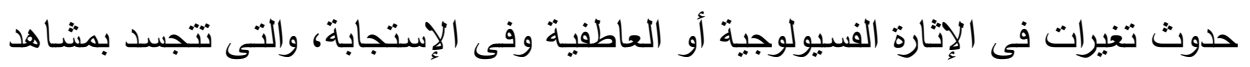
العنف وبعاطفة العدوان. - مان.

تبدلات الموقف التى يترتب عليها التعرض إلى مشاهد العنف وظهور عاطفة العدوان.

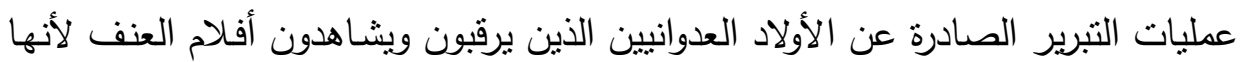
تزودهم بالغرض لتبرير سلوكهم العدوانى على أساس كونه عادياً (ء).

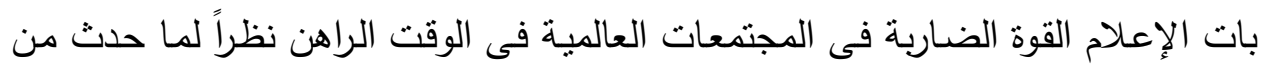

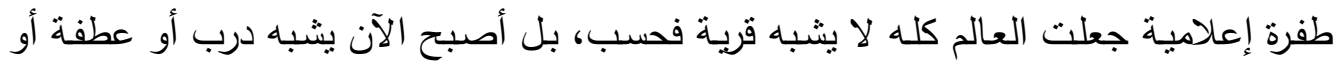

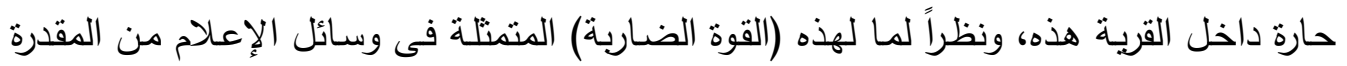
على النفاذ إلى عقل ونفس المتلقى سواء بالصوت والصورة عبر شاشـة التليفزيون وما يصاحبها

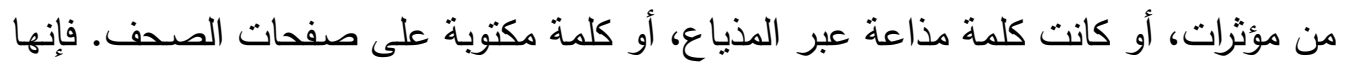
قد أدت إلى تمكن المتلقين من استقبال أحداث وجرائم عنف تؤونى إلى تغيير الحالة النفسية والقيمية والإجتماعية لدى مستقبليها ومتلقيها، وأدى إلى وصول العنف وأحداث التخريب وجرائم

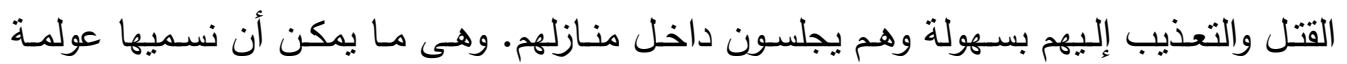
الإعلام أو العولمة النقافية. "ولقد صاحب التطورات التى يشهـها العالم الآن فى ظل ما يسمى بالعولمة ظهور أنواع العهاع

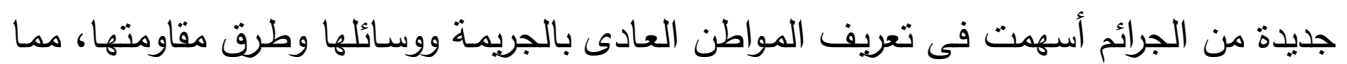
أدى إلى ضرورة زيادة وعيه الثقافى مستشعراً اخطار الجريمة، وأثرها السلبى على الجى المجتمع (ro).

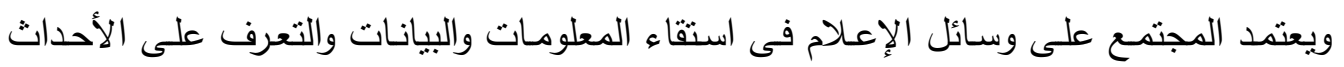

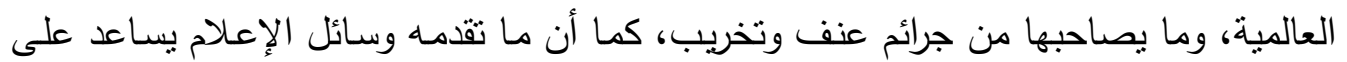
ترسيخ المعلومات وتتبع الذهن والنفس بالمحتوى والمضمون، وتسيطر على الفكر الصورة التي وني

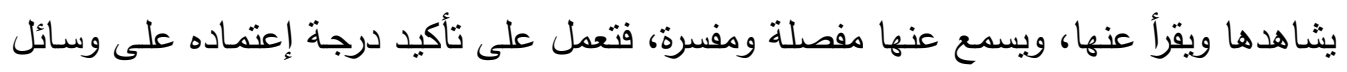
الإعلام في تلقيه المعلومة. درجة الاعتماد على المطلومات :

- وتتوقف درجة إعتماد أفراد الجمهور على المعلومات التى توفرها وسائل الإعلام على أمرين: 1. أ. درجة الثبات والإستقرار داخل المجتمع.

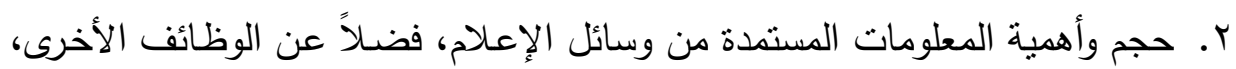
التى تضطلع بها هذه الوسائل في المجتمع. 
ركائز الاعتماد على وسائل الإعلام :

وتقوم علاقات الإعتماد على وسائل الإعلام على ركيزتين أساسيتين هما:

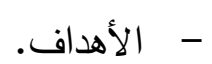

- المصسادر : حيث تتحكم وسائل الإعلام في ثلاثة مصادر من مصسادر المعلومات هي (جمع المعلومات - تتسيق المعلومات- نشر المعلومات والقدرة على توزيعها

$$
\text { على جمهور غير محدود) (ri). }
$$

تنصـدر نظريـة الاعتمـاد على وسـائل الإعـلام بـاقي النظريـات الإعلاميـة في مثنل هذه

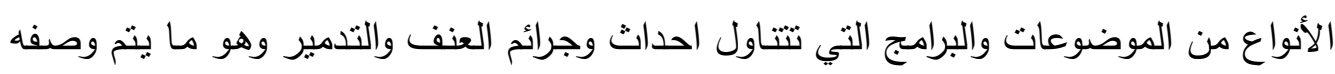
بإعلام الأزمات، ولهذه النظرية ما ييرر وجودها في منل هذه الأحداث. فروض نظرية الاعتماد على وسائل الإعلام: - وتقوم نظريـة الإعتمـاد على وسـائل الإعلام على مجموعـة مـن الفـروض الإعلام الفرعيـة، تـأتي في طليعتها:

ا ـ تختلف درجـة استقرار النظـام الاجتمـاعي وتوازنـهـ نتيجـة التغيـرات المستمرة، وتبعـا لهذا

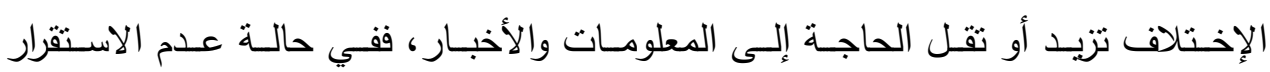
الاجتماعي تزداد المعلومات فيكون الأفراد أكثر إعتماداً على وسائل الإعلام.

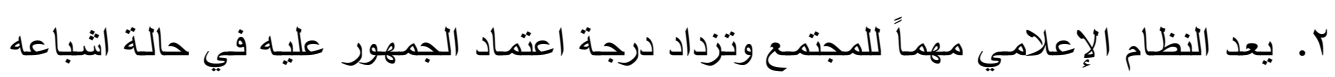
حاجاته. r. يختلف الجمهور في درجـة اعتمـاده على وسـائل الإعـلام نتيجـة اختلافهم في الأهداف

$$
\text { والحاجات الفردية (rv). }
$$

العنف ضد المرأة: الأسباب والآثار والعلاج:-

أسباب العنف ضد المِرأة : ونحاول في هذا المختصر إلقاء الضوء وأعلى على الأسباب الكامنة خلف هذا النوع من العنف:ا ـ تعتبر المرأة نفسها هي أحد العوامل الرئيسية لبعض أنواع العنف والإضطهاد لسكوتها على العنف. r. الأسباب الثقافية: كالجهل وعدم معرفة كيفية التعامل مع الآخر وعدم إحترامه.

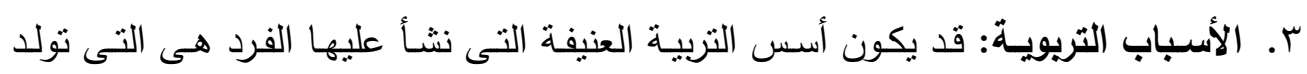
لديه العنف. 
ع. العادات والتقاليد: هناك أفكار متجذرة تحمل في طياتها الرؤية الجاهلية لتمييز الذكر

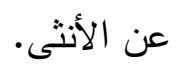

ه. الأسباب البيئية: فالمشكلات البيئية التي تضغط على الإنسان فتدفعه نحو العنف لينفجر

$$
\text { فيمن هو أضعف منه. }
$$

7. الأسبـاب الاقتصـادية: فالخلل المـادي، والتضـخم الاقتصـادي يؤديـا إلى العنف، وتقبل المرأة هذا العنف للصرف عليها. V. عنف الحكومـات وإلسـلطات: بسبب سن القوانين التي تعنف المرأة، أو تؤيد من يقوم بتعنيفها (†^) ـ آثنار العنف ضد المر أة: تترتب على العنف الممارس ضد المرأة آثار جسمية ونفسية وإجتماعية، تصبي المرأة وتكون آثارها على الأسرة والمجتمع: (أضرار جسدية ونفسية- شعور المرأة بالخوف وإنعدام الأمان - الحد من إمكانية حصولها

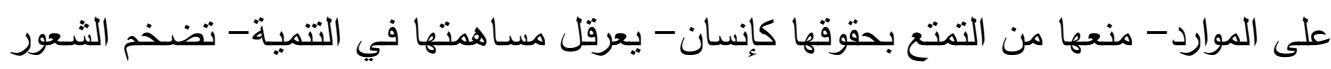

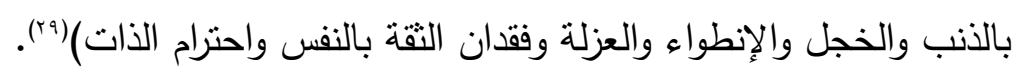
علاج العنف ضد المرأة: - الرجـوع إلى القانون الإلهـي والثـريعة الإسـلامية التي تعطـي للمـرأة كامـل حقوقها وعزتهـا

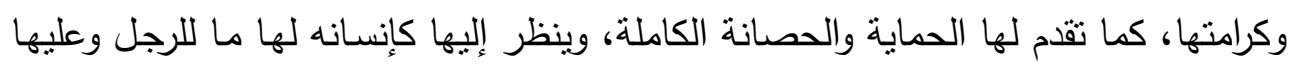

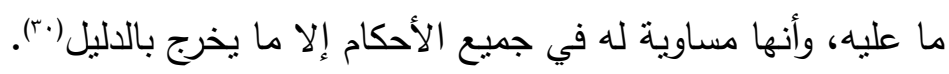

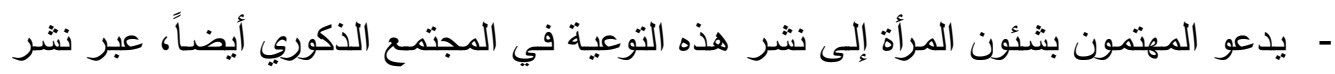

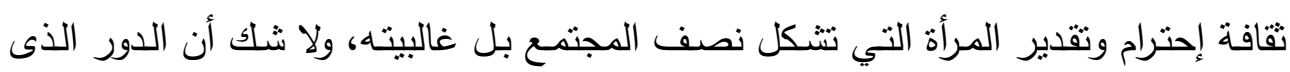

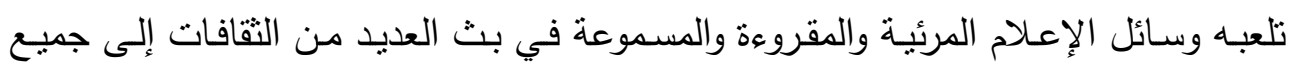

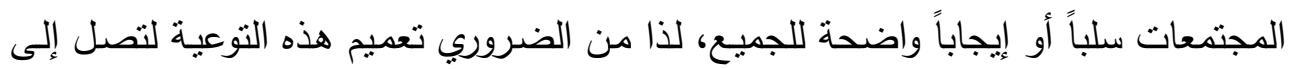
هذه الوسائل لتقوم بالتغطية اللازمة لذلك، ومضاعفة هذه الجهود بالنسبة لوسائل التلفزة("r).

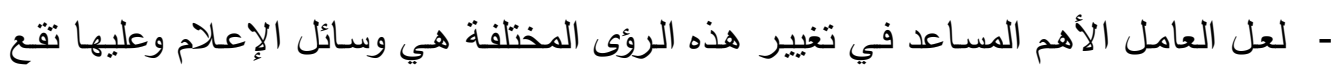

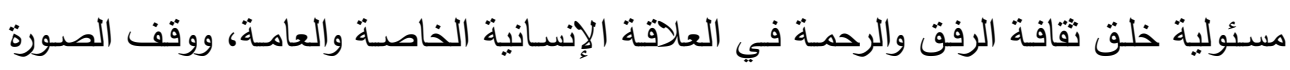

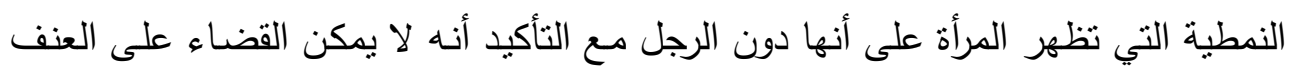
ضد المرأة من دون الإرادة السياسية(rr). 


\section{العنف المدرسي:}

- وهناك نوع آخر من العنف هو العنف المدرسي:

يقصد بـالعنف المدرسي: العنف بين الطلاب أنفسـه، أو بين المعلمين أنفسهم، أو بين المعلمين والطلاب وهذه الحالات مجتمعة نشير إلى العنف المدرسي الثـامل الذى تسوده حالة من عدم الإستقرار وتظهر منه بكل وضوح عدم القدرة على السيطرة على ظاهرة العنف المنتشرة بين الطلاب أنفسهم أو بينهم وبين المعلمين. كما يشير هذا المفهوم إلى التخريب المتعمد للممتلكات حيث يطلق عليه تسمية العنف

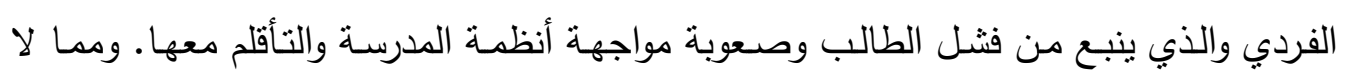
شك فيه أن للعنف المدرسي تأثيرات سلبية كبيرة تنعكس على الطلاب وبظهر هذا في المجال السلوكي والتعليمي والاجتماعي والانفعالي، وينطبق هذا على العنف الجامعي والعنف المؤسسي الــى يحـدث في المؤسسـات الحكوميـة بـين المـوظفين وبعضــهم البعض، أو بـين المـوظفين ولين والمترددين على المكان. وعلى وسـئل الإعـلام أن تعمل جاهدة بكل طاقاتها ومالديها من إمكانيات لتوضيح تلك

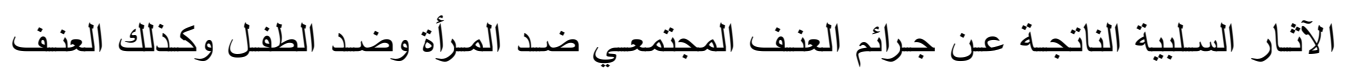
المدرسي والجامعي والذى يحدث بالمؤسسات الحكومية وإظهار الأضرار الناجمة عنه وما يتلوها من تخريب ومن الجائز تذمير للأخلاق والممتلكات والنفس البشرية، والعمل على إظهار الوجها الآخر للآثار الإيجابية التي تتتج لمن ينتهج أسلوباً بعيداً عن العنف، بل إنه إن صـادفه العنف بذل الجهد المضني كي يمنع حدوث آثاره السلبية، أو ان يعمل على تغييره إلى سلوك حميد يثاب عليه فاعله، ويأتي بثمار طيبة يجنيها صاحبه وتعود بالفائدة على المجتمع، وعلى وسائل الإعلام أن تسعى للإقلال من تقديم ما هو فيه إسـاءة للطفل والمرأة حتى لا يعتاد عليه الطفل أو المشاهد فتكون مادة إعلامية واجتماعية مستشاغة له. المبحث الثاني : سياسات واستراتيجيات مكافحة العنف، وإجراءات مكافحته المطلب الأول: سياسات واستراتيجيات مكافحة العنف: يعد الإعلام سلاحاً ذي حدين إما أن يرتقى به الإنسان، وإما أن يتدنى بـه، فهو يؤثز على سلوكه وإتجاهاته، والإعلام قد يصل بالإنسان إلى درجة من السمو والرقي الأخلاقي، وقد يصل به إلى درجة التطرف والعنف، ويظهر ذلك جلياً في جهاز التليفزيون حيث أنه الأقوى تأثيراً في نفوس مشـاهديه كباراً وصغاراً، ويعود السبب في ذلك إلى أنه يصـل للمشـاهدين في أي مكان 
وكل زمان دون تقيد أو شروط من جانب المشاهد لـه لذا كان من الواجب وضـع إستراتيجية

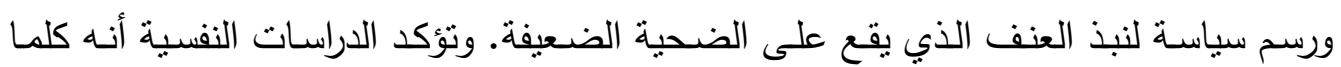
كثرت مشـاهدة الأطفال لبرامج العنف إزدادوا تقبلاً للسلوك العدوانى الذى يصبح أمراً طبيعياً

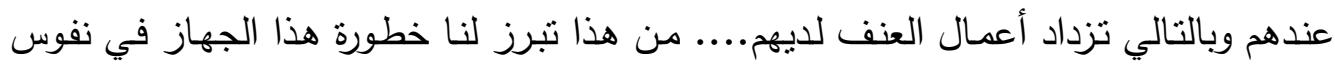
المشاهدين وعقولهم.... والمعالجة: - ل لابد أن يدرك القائمون على أجهزة الإعلام المسئولية أمام اله .. وأن براجعوا ضمائرهم حيال

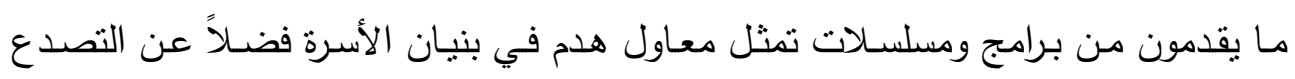
الإجتماعى وشيوع العادات المستهجنة.

- مراجعة جميع البرامج والمسلسلات قبل تقديمها للمشاهدين وحذف ما يسئ إليهم فيها. - - زيادة الجرعات الدينية في خطة البرامج فهى قلبلة والقليل منها لا يؤدي دوره المنشود (؟r).

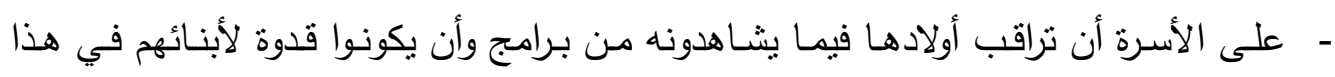

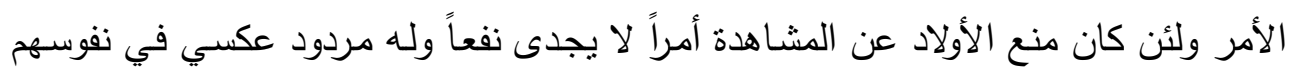

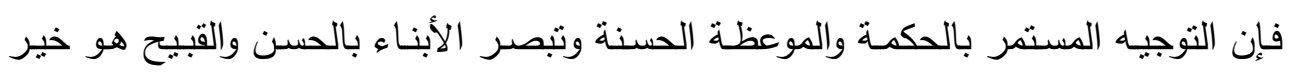

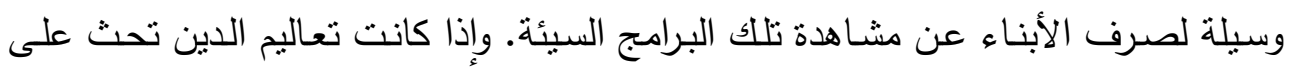

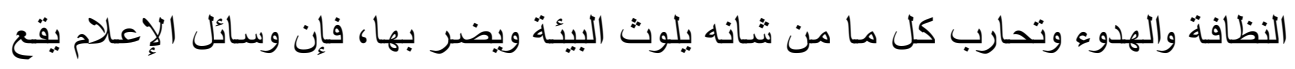

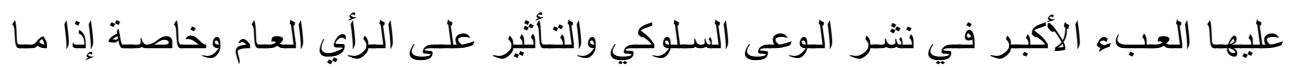

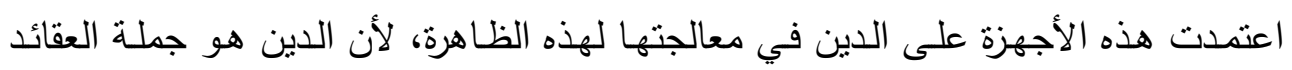

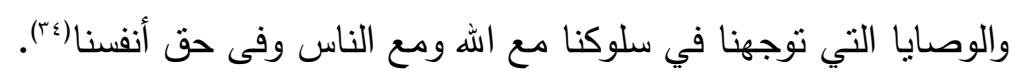

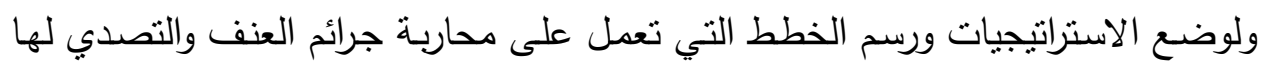

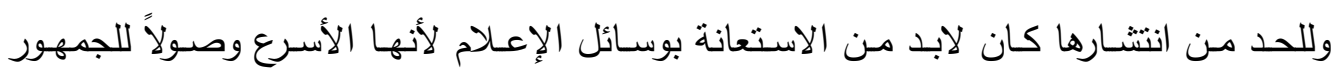

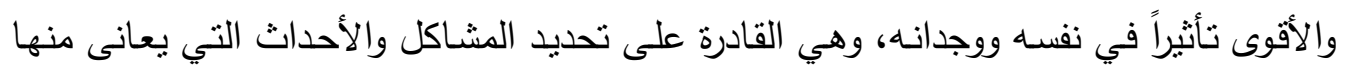

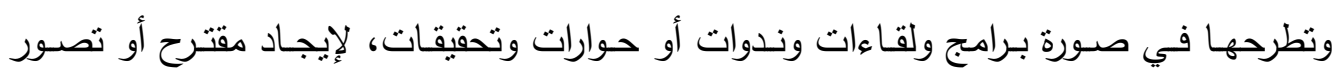

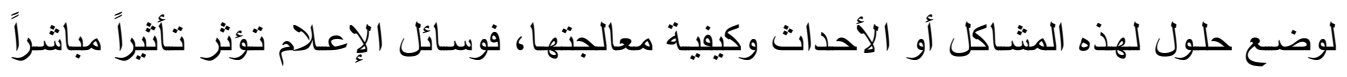

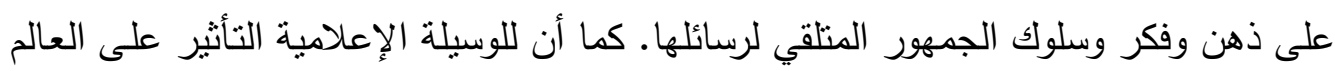

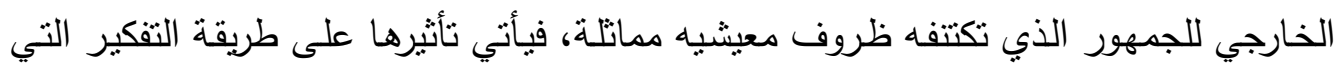

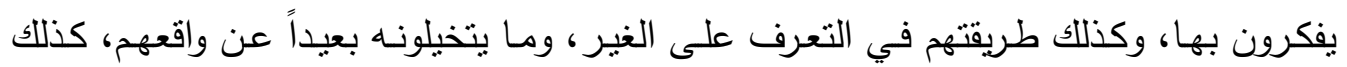
طريقة القراءة، والاستماع والمشاهدة لما يحيط بهم وبالمجتمعات الأخرى التي لا يصلون إليها. 
هذه الإستراتيجية تجعل المجتمعات على علم بما يدور في مجتمعات أخرى من احداث

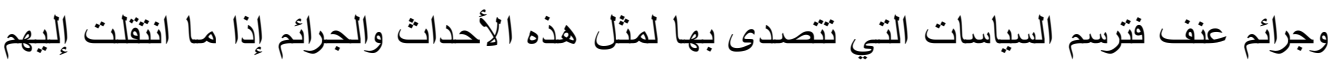

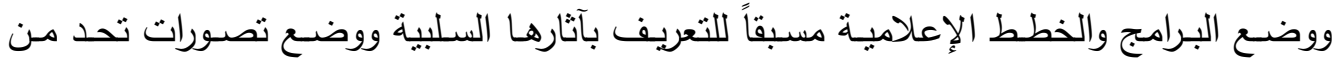

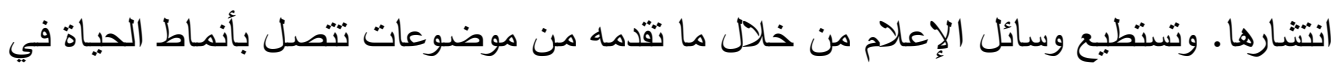

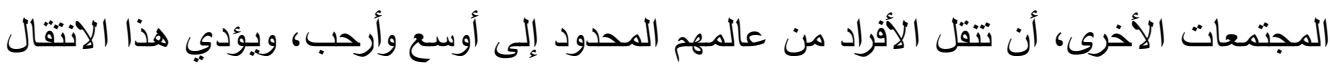

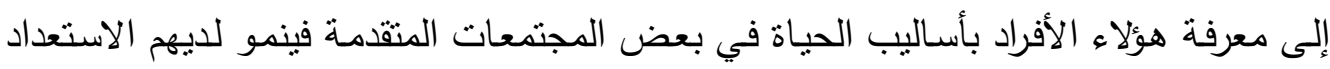

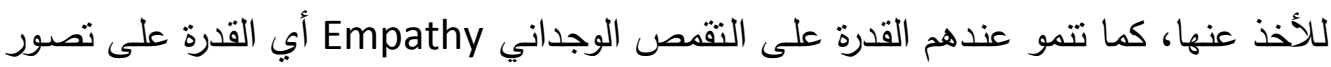

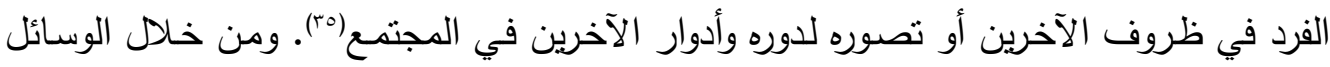

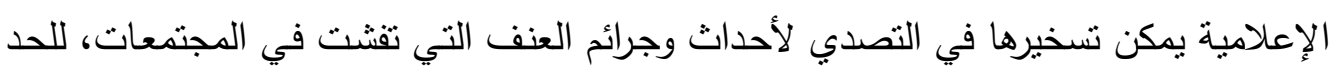

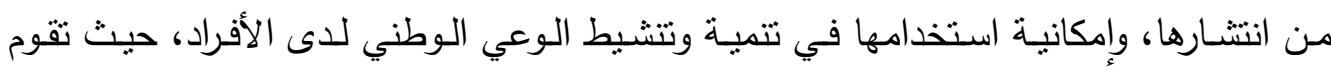

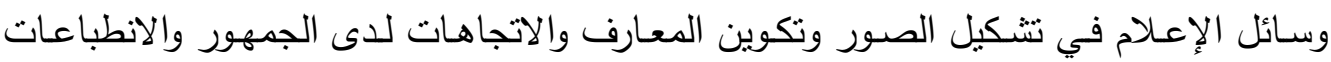

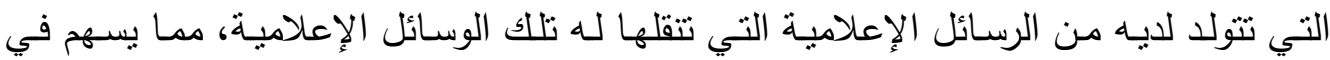
تكوين رأى عن كيفية مكافحة جرائم العنف. فقد أصبح هناك شبه اتفاق على أن وسائل الإعلام تقوم بدور يعتد بـه في تحقيق الوعي

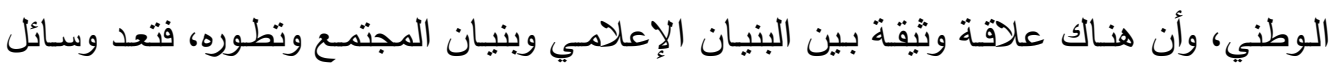

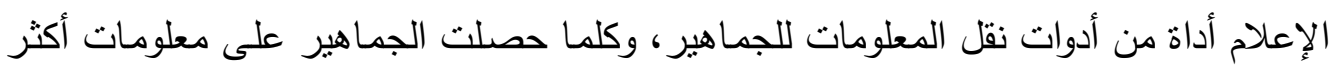

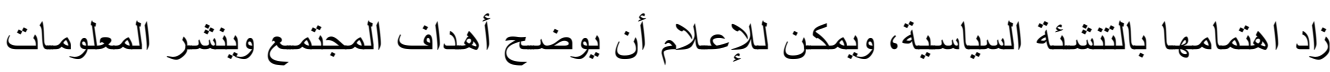

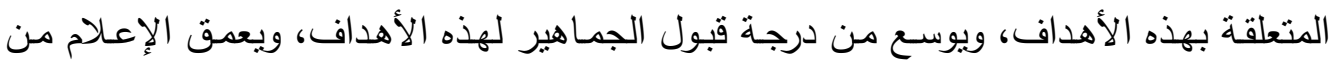

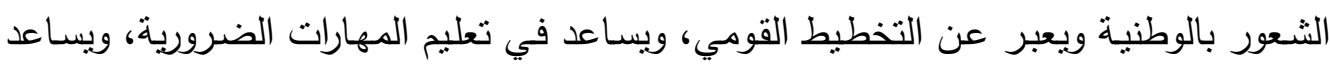
الجماهير على أخذ المستقبل بعين الاعنبار (ج). بذلك يمكن نبذ العنف والأحداث الإجرامية بالتركيز على التتمية التي تفيد الوعي والفهم

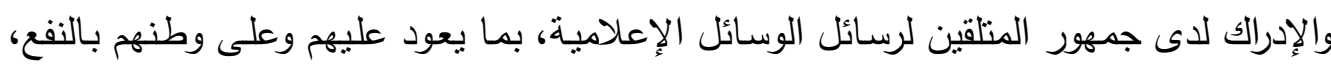
فمن خلال الوعي الوطني يزيد حبهم لوطنهم ويريدون له السلامة من أي سوء، وأن يحل السلام

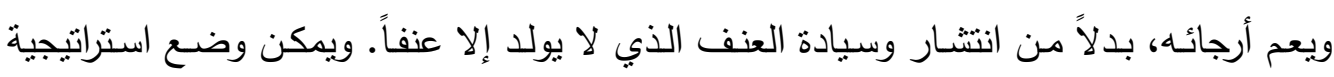

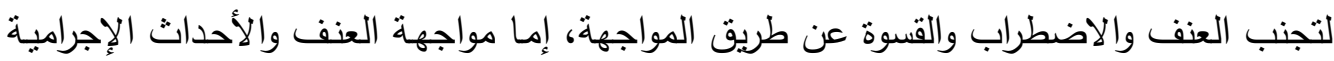

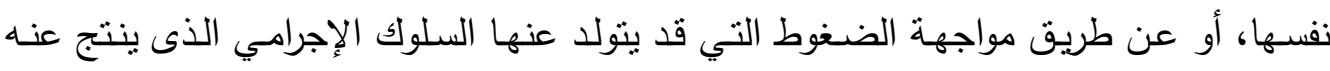

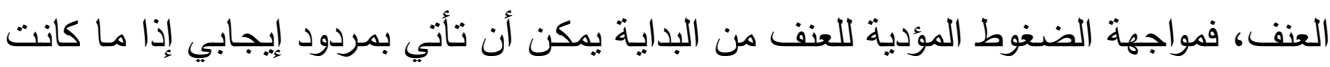
في بدايتها قبل أن تستفحل وتستبد. 
الخطط والإستراتيجيات الإيجابيـة أو السلبية التي بستخدمها الفرد شعورياً أو لا شعورياً،

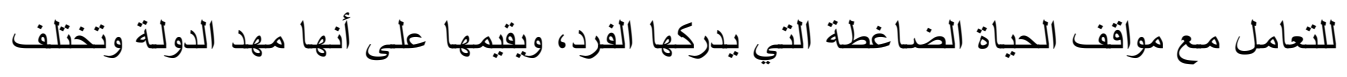

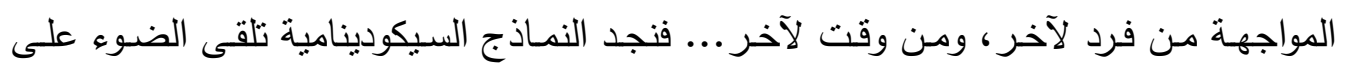

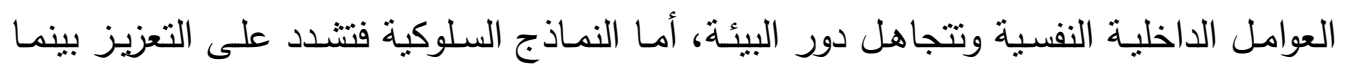
تتجاهل في الغالب العوامل البيئية والمعرفية(rV). وعلى أية حال فإن تعديل سلوك محدد يستغرق

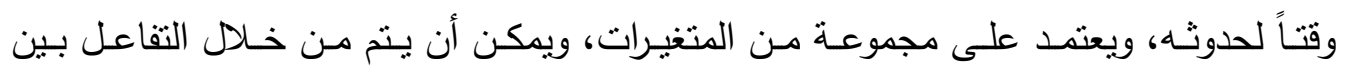

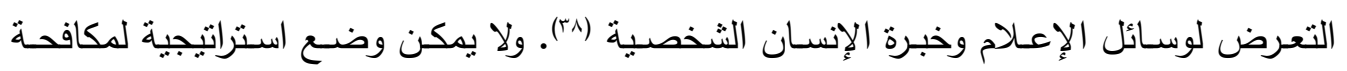
العنف الإرهابي إلا أن تكون تلك الاستراتيجية على الصعيد الدولي، ولا يتمثل ذلك في هيمنة

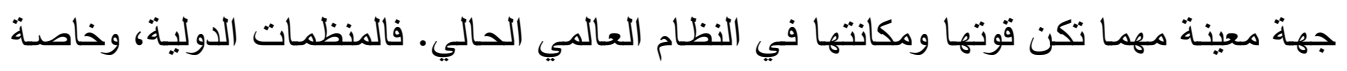
منها الأمم المتحدة هي الكفيلة بوضع برامج للبحث في فئه خطر العنف الإرهابي، وعواقبه الثاملة على الوضع العالمي الراهن (9a). علينا البدء في أن نكون واقعيين، وعلينا أن نعترف بأن العنف جزء من علافتتا أو لنقول

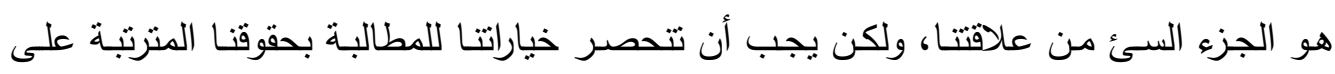

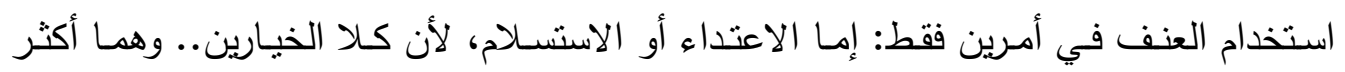

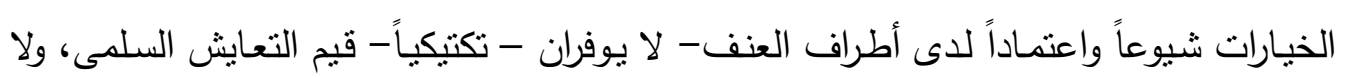

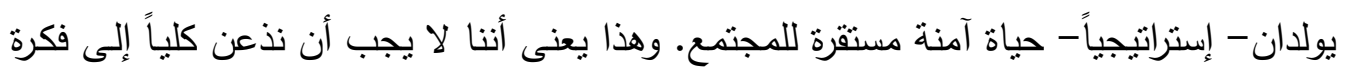

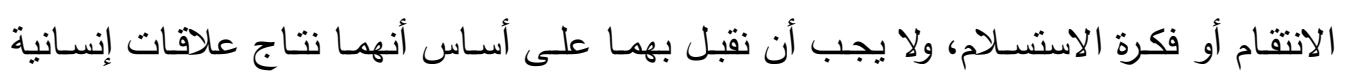

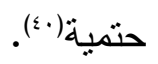

لذا كان لابد من الاهتمام بالمؤسسات التربوية لكونها من المؤسسات ذات الثـأن العالي

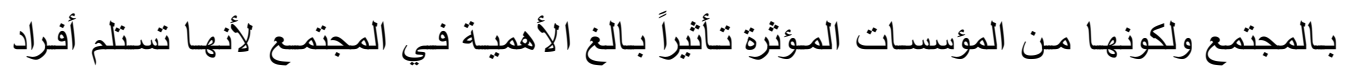

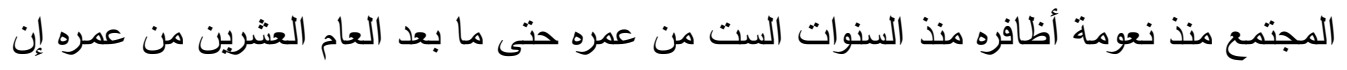
كان جامعياً أو ما قبل العشرين إن كان تعليماً منوسطاً، وهي تعمل على على تكوينهم فكرياً وثقافياً

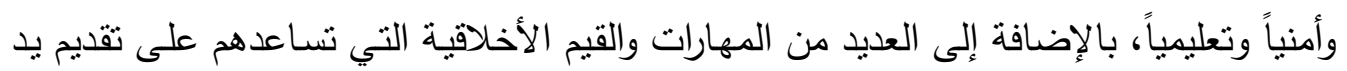

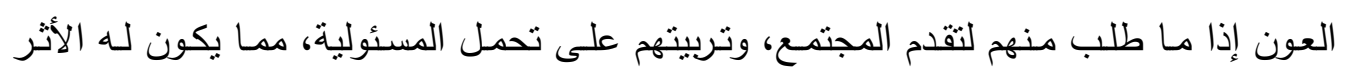
الإيجابي الطيب في أن بسود المجتمع الحب والعدل والسلوك السوى بعيداً عن السلوك العدواني ويحارب العنف والفساد. 
إن بناء استراتيجية تدريسية واضحة تؤدي إلى تفعيل دور الطالب في المواقف التعليمية،

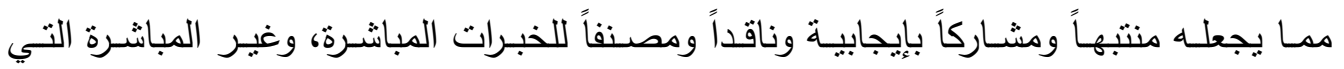

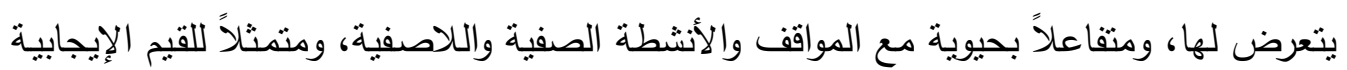

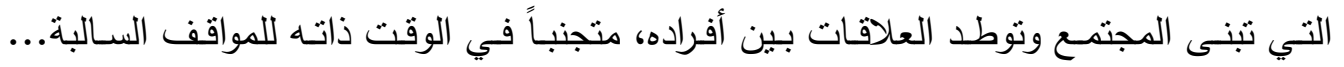

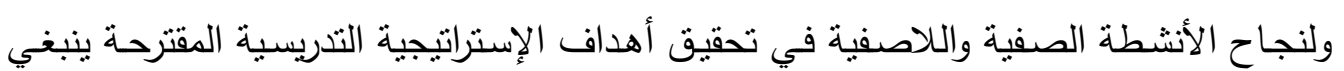

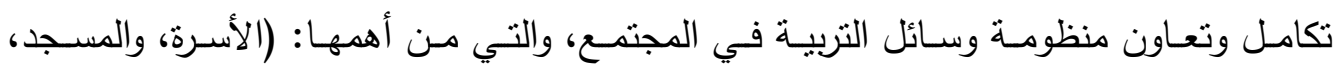

والمدرسة، والأندية، ووسائل الإعلام المختلفة، والمؤسسات الأمنية، والمؤسسات الخدمية....) (1).

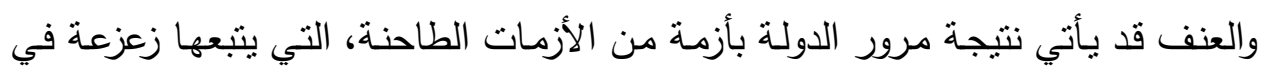

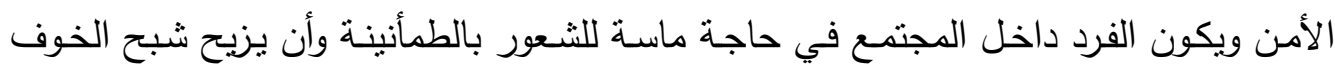

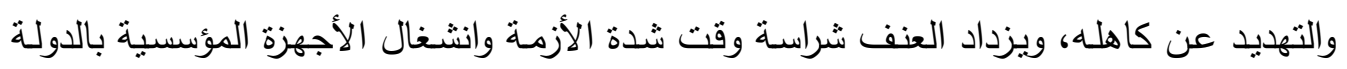

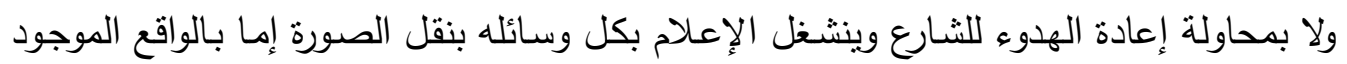

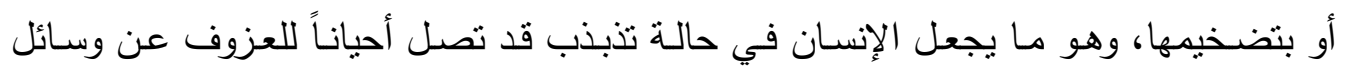

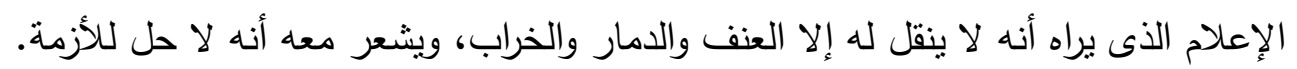

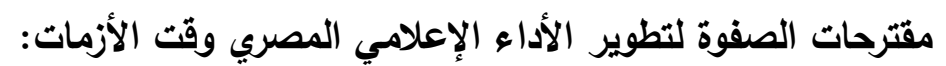

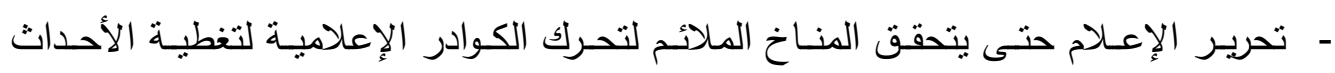
بأبعادها المختلفة. - - الالتزام بالمصداقية والرغبة في إبراز الحقائق. - الاهتمـام بالتخصص الإعلامسي في أداء الكوادر الإعلاميـة لمهامها مـع الاهتمام بتطوير الأداء المهني. - ت تطـوير أدوات الرســالة الإعلاميــة وتغييـر مســاراتها حتـى يتحقـق لهـا السـبق واختـراق

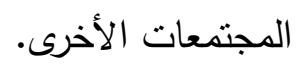
- ضرورة اعتماد الإعلام المصري، بل والعربي على ثلاثة عناصر رئيسية تمثل جوهر العمل الإعلامي الناجح وهى: العقلانية، الحيادية، والتوازن. - ت توسيع شبكة المراسلين في مواقع الأحداث الساخنة. - - تقصيل الاهتمام بالصورة التليفزيونية. - - اعتماد مفهوم الثنائية في مجال الإعلام أي الاهنمام بالإعلام الرسمي والإعلام المعارض لـاض على حد سواء. - تطـوير أداء فريـق العمـل الإخباري في التليفزيـون المصـري لمتابعـة الأحـداث على مـدار

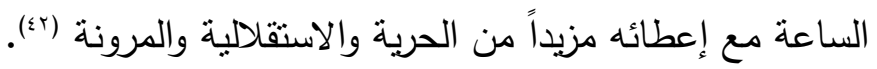


المطلب الثاني: إجراءات مكافحة جرائم العنف: أنشأت وزارة الداخلية المصرية مؤخراً إدارة جديدة باسم "مواجهة جرائم العنف ضداءت المرأة"،

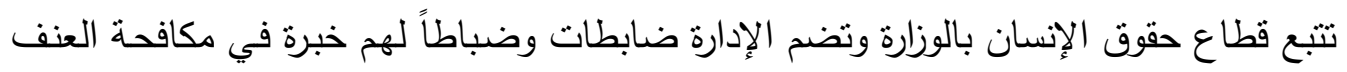

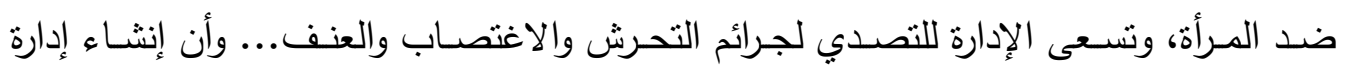
جديدة لمتابعة جرائم العنف ضد المرأة يأني في ضوء اهتمام وزارة الداخلية بحقوق المرأة والعمل

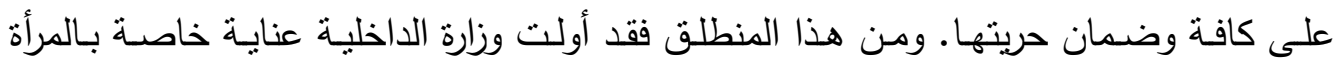
وسبل حمايتها والتصدي بكل قوة وحسم لأى شكل من أثنكال العنف الذى يمكن أن يقع عليها

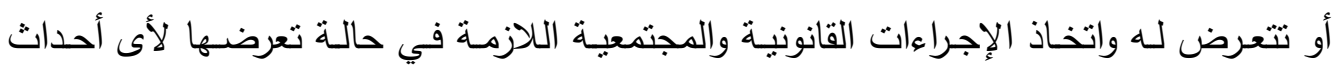

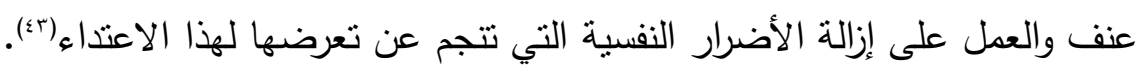

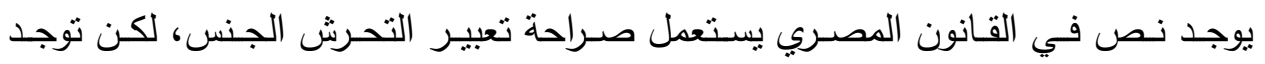

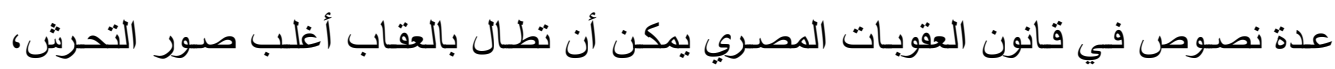
نذكر منها:

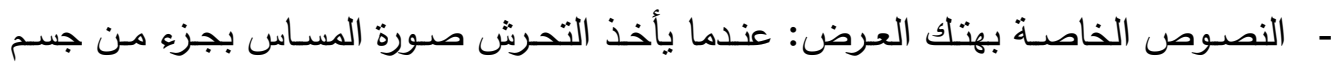

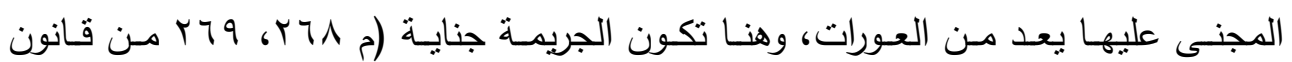
العقوبات). - النصـوص الخاصـة بجريمـة السـب العلنـي: عندما يتمثل التحــش في ألفـاظ تخل بحيـاء المجنى عليها (م ؟ • ب من قانون العقوبات).

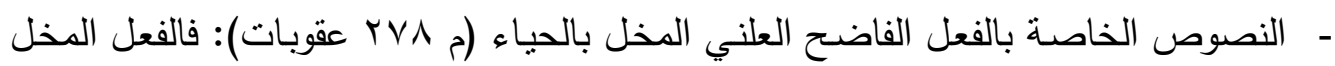
بالحياء هو الذي يخدش في المجني عليه حياء العين والأذن.

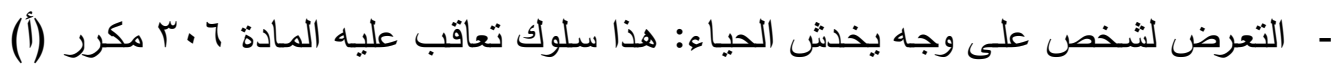

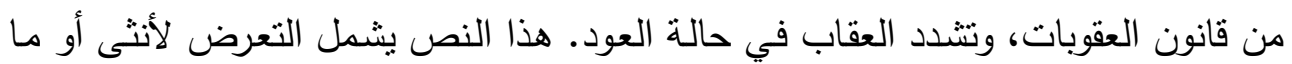

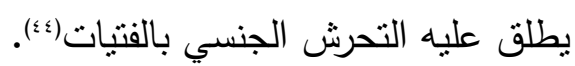

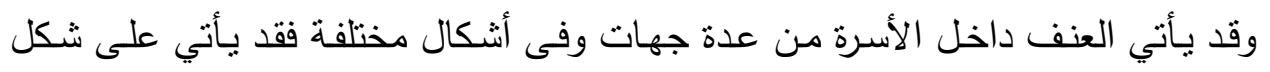

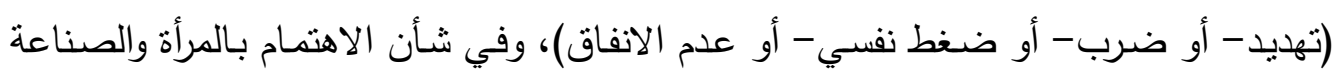

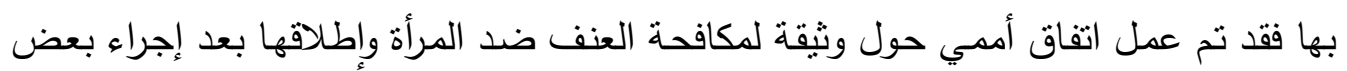

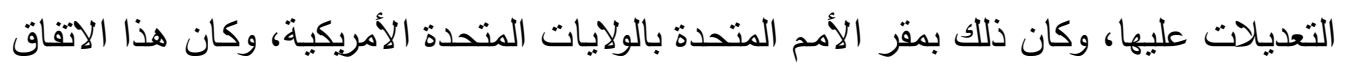

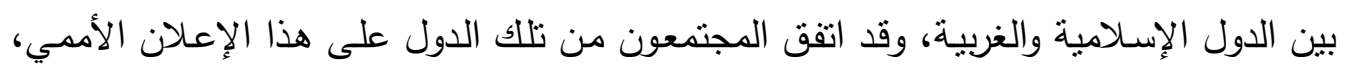
وكان حول مدونة سلوك مكافحة العنف ضد النساء. 
يشار إلى أن الوثيقة الأممية لرفع أشكال التمييز والعنف ضد المرأة، تتضمن عدداً من

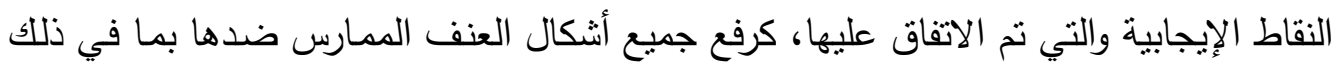

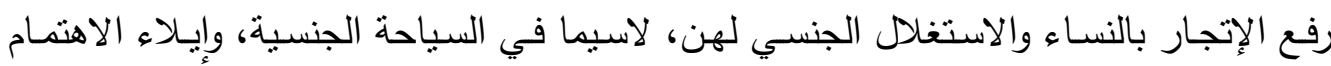
البالغ بقضية التربية الجنسية، لكن في المقابل تتضمن بعض النقاط الناط التي تتعارض مـع الأحكام

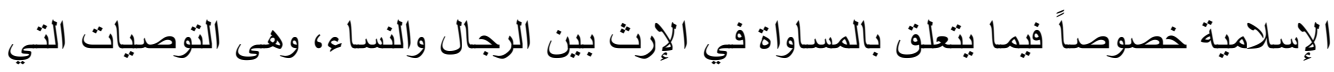

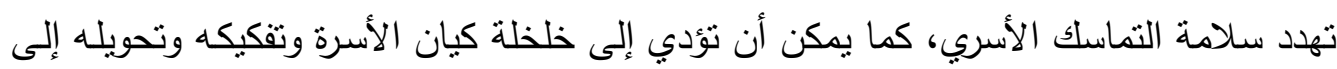

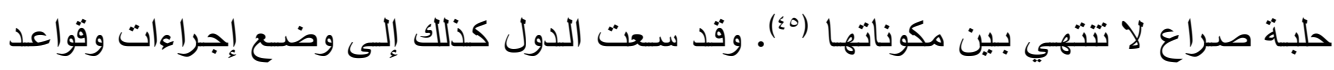
تعمل على التصدي للعنف الأسري وبخاصة ضد الأطفال لإيجاد علاج لهذه الظاهرة. الحلول والإجراءات العلاجية للصد من ظاهرة العنف الأسرى ضد الأطفال.

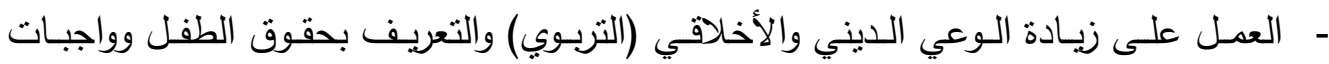

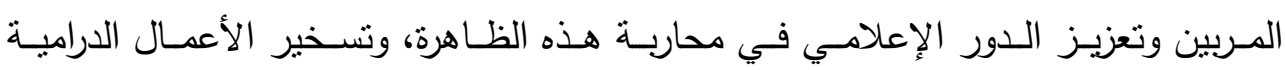
لخدمة هذا.

- مضع الأنظمة والتشريعات التي تضبط أسلوب التعامل مع الأطفال في المدارس.

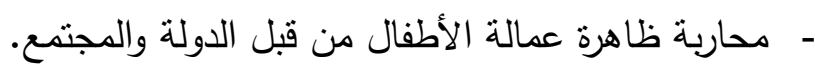
- - تقنين العمل التطوعي ومتابعته ووضع الحلول الناجمة لتسرب الأطفال من المدارس.

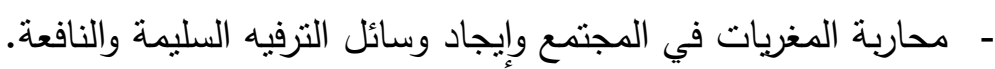
- تعزيز الحريات السياسية للابتعاد عن حالات الكبت السياسي التي قد نظهر في صور سلبية متعددة من بينها الاعتداء على الأطفال("i). ومـع أن لهذه الظاهرة وهى ظـاهرة العنف آثارها السلبية التي تظهر على الفرد، ويكون بظهور تدنيه في مستواه التعليمي في الدراسة وضعف تحصيله العلمي، وهروبه من التعليم، مما

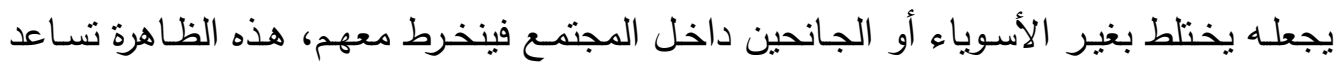

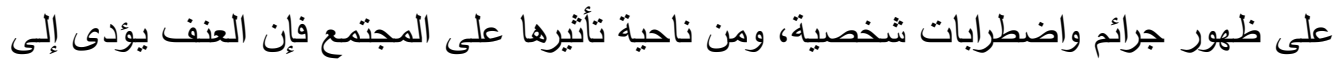

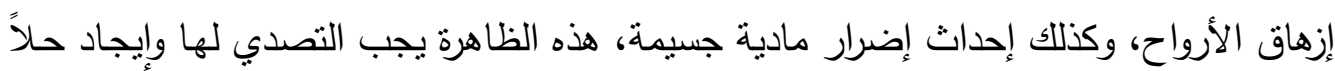

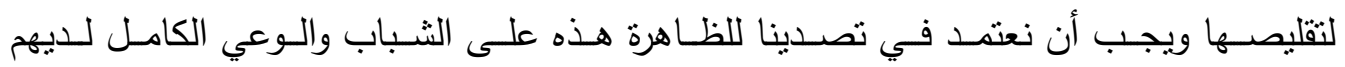
نظرًا لخطورتها.

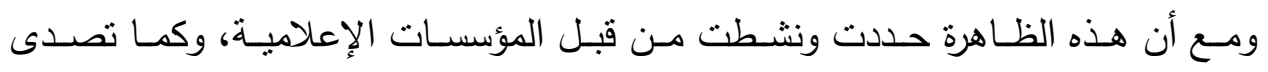

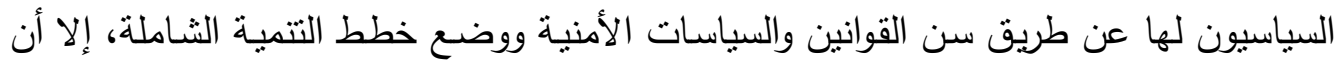

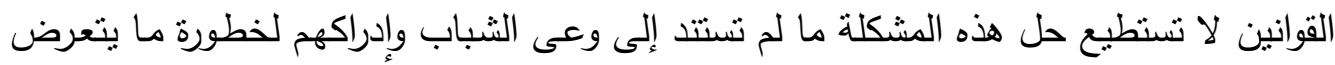


له مجتمعه، لذا أدرك المجتمع أن الحل الجذري لكل الأزمات والظواهر المشكلة يكمن في قيام

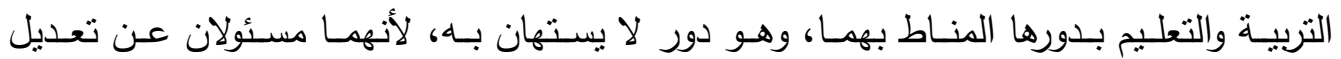

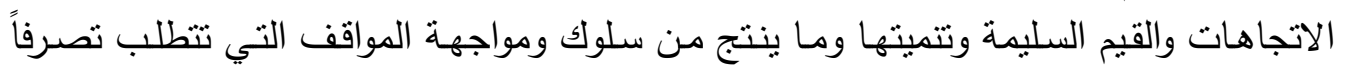

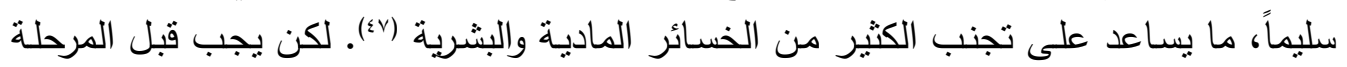

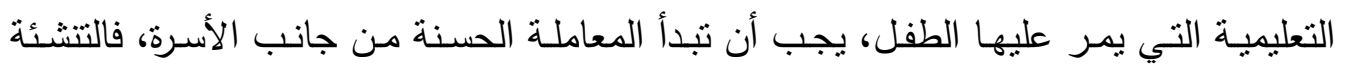

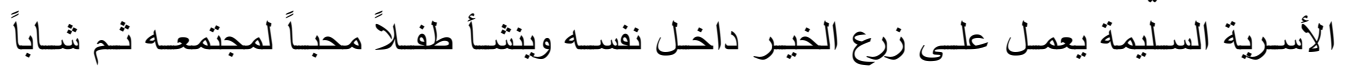
مفيداً لوطنه.

التتشئة الأسـرية السليمة تأمر كل مـن لـه علاقة ومسؤولية التوجيه والتربيـة، أن يحسن

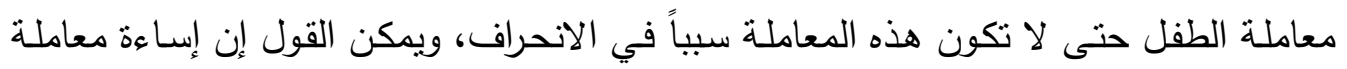

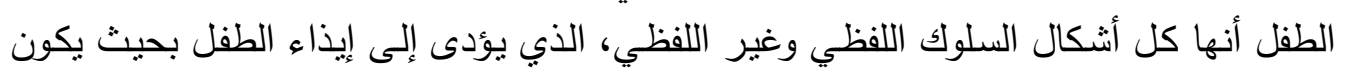

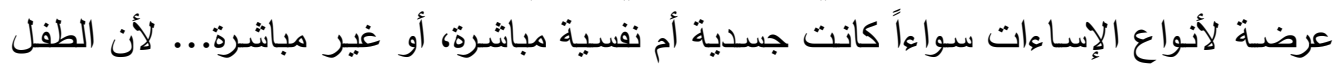

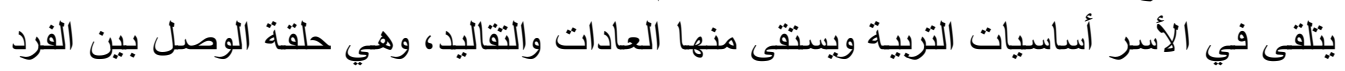

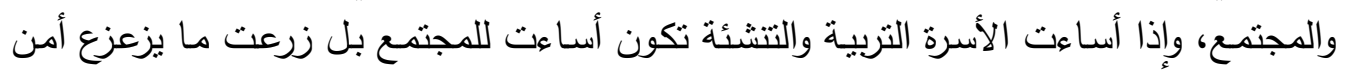

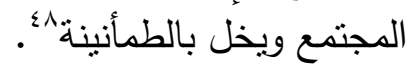

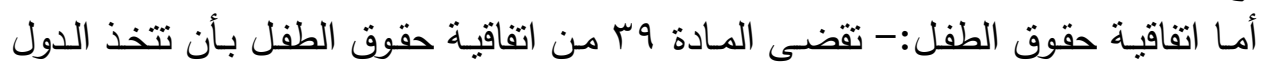

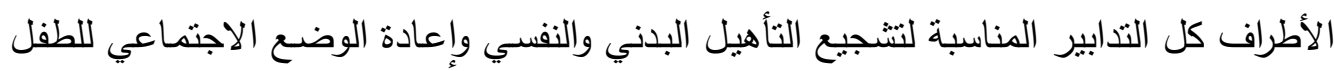

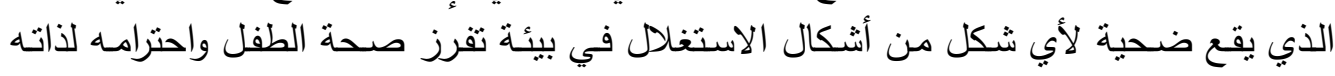

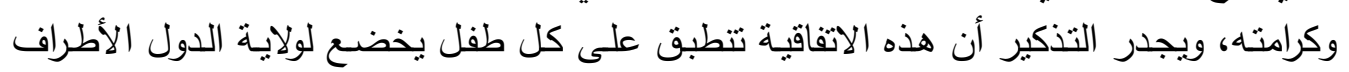

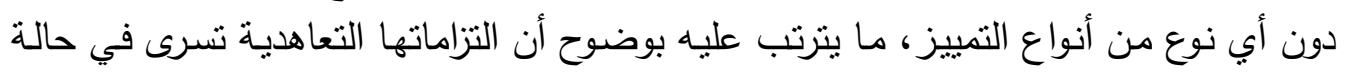

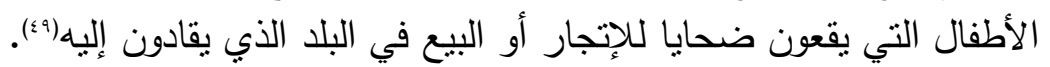

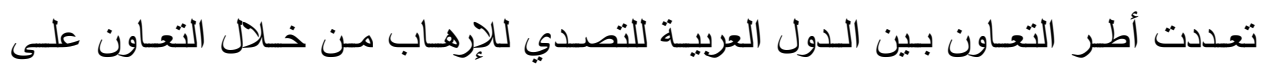

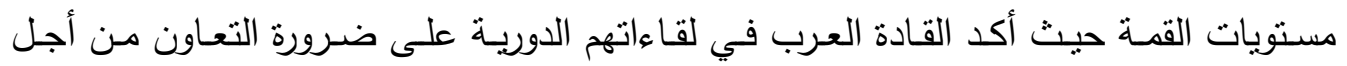

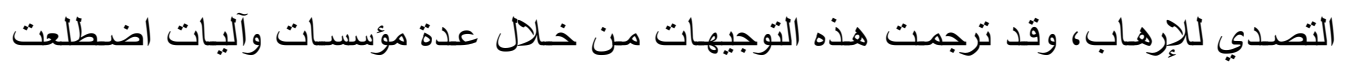

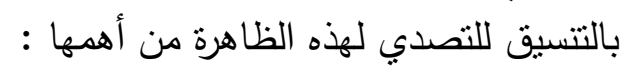

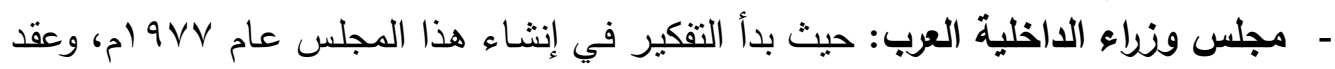

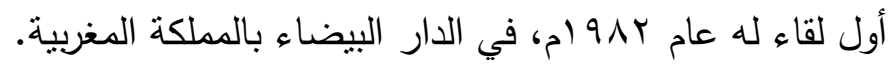

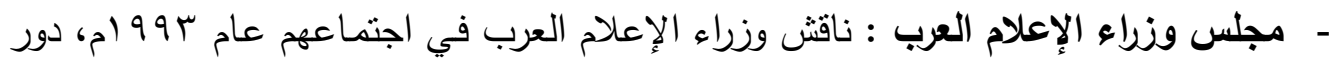

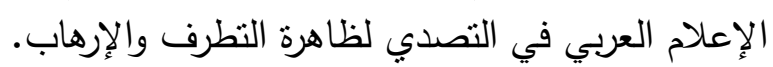

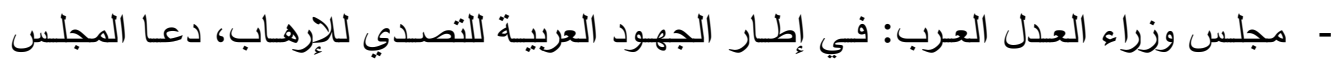

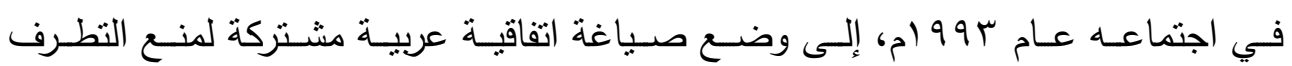
والتصدي للإرهاب. 
- المنظمة الدوليـة للشرطة الجنائية (الإنتربول): عقدت المنظمـة دورتها رقم VT في القاهرة

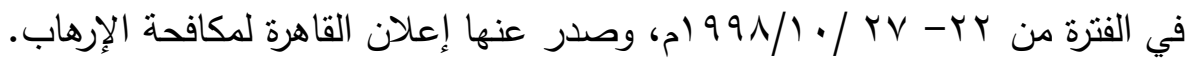

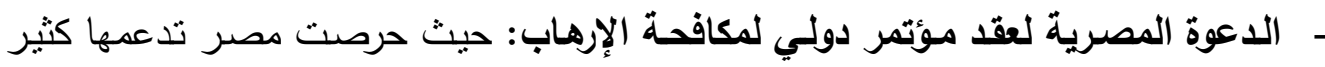

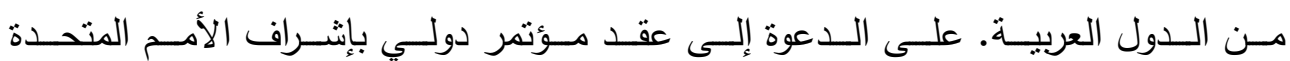
لمكافحة الإرهاب. - الندوة العلميـة حول تثريعات مكافحة الإرهاب في الوطن العربي: عقدت هذه الندوة في

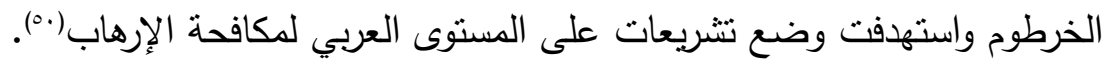

خاتمة البحث

تسـى وسـائل الإعـلام دائهـاً وأبداً لتحقيق عدة أهداف، في مقدمتها إثباع المتلقي بما

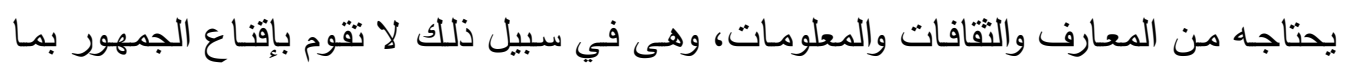

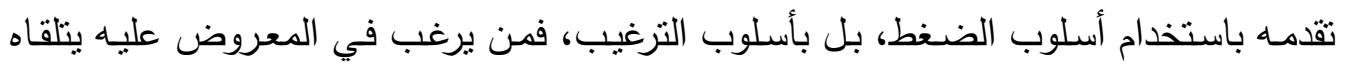

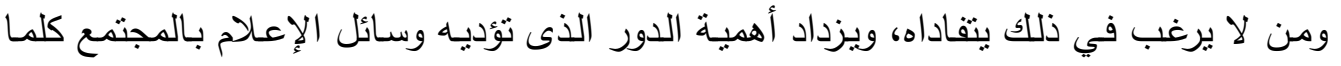

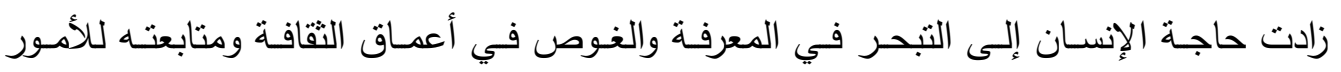
والأحداث التي تمر بها بلده وبلدان العالم، والحكم على المطروح منها بأنه غت ألث أو سمين.

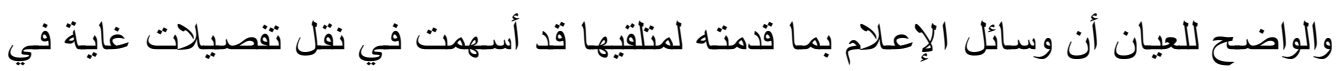

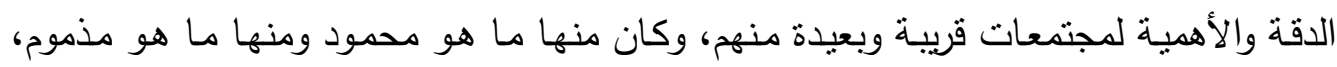

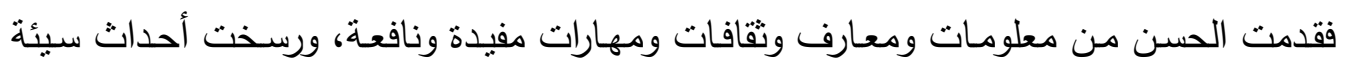

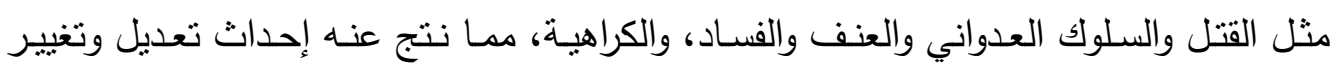

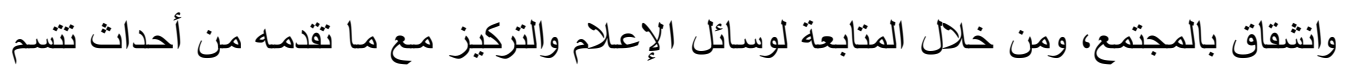

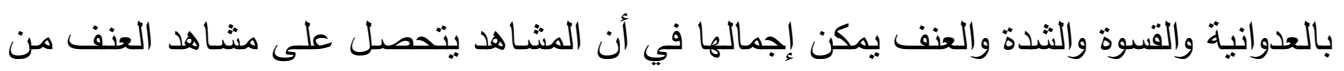

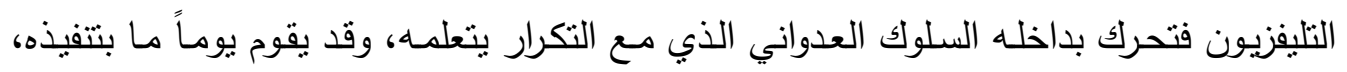
حيث أن تلك المشاهد تشاعد المشاهدين لإيجاد ما يمكن بـه أن يجعلوا سلوكهم العدواني أمراً

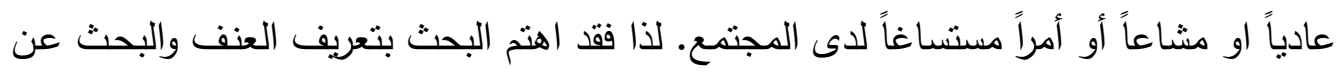

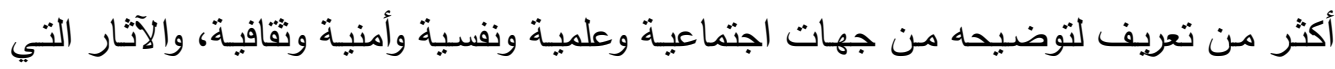

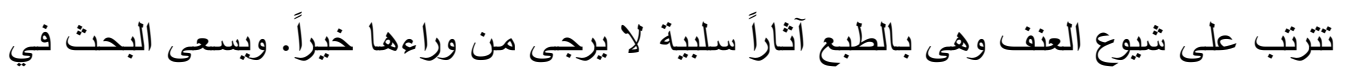

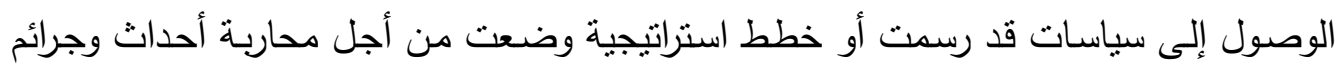

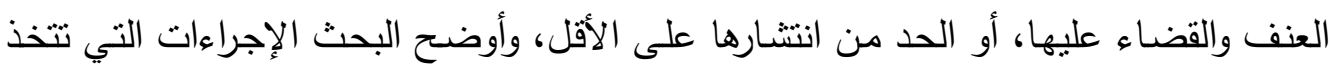

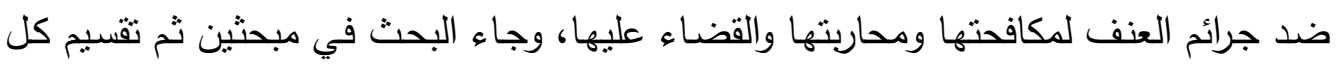

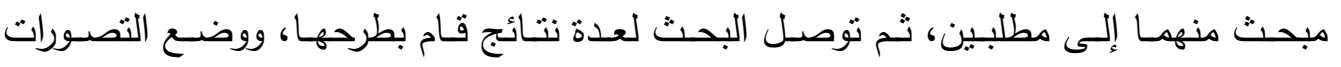
والمقترحات التي توصل إليها الباحث وطرحها بالبحث. تُبـ 


\section{نتائج البحث}

خلص البحث إلى عدة نتائج منها:

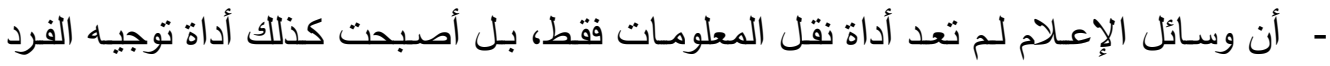

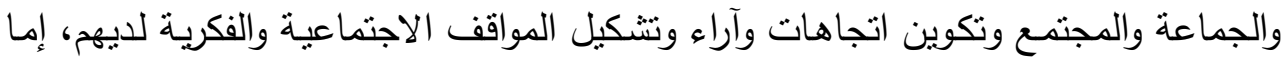

$$
\text { لإنتاج العنف أو لمحاربته. }
$$

- أن وسائل الإعلام دخلت مرحلة تتافسية مع المؤسسات التربوية والتعليمية، والذي هو نتيجة لكافة المظاهر التي أفرزتها الوسائل الإعلامية للإنتاج التقافي أو الفكري، التي تتولى لتئية نشرها بين الجماهير على اختلاف فئاتها بدءاً من الأطفال ومروراً بالثباب وانتهاءاً بكبار السن.

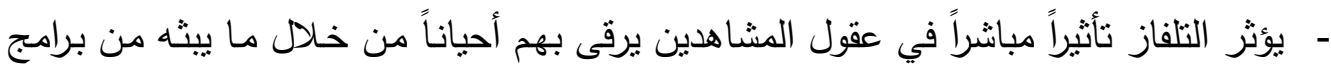

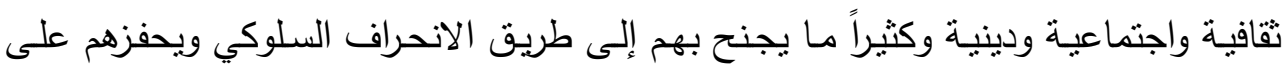
الانسلاخ من القيم الأساسية العليا والتردي في هوة المفاسد المهلكة وممارسة جرائم العنف.

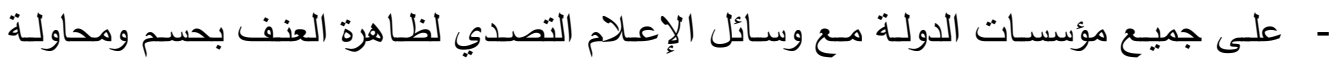

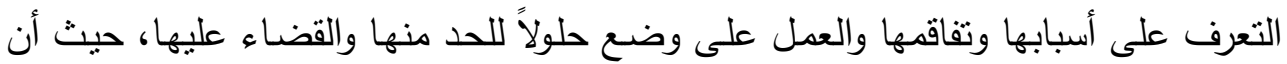

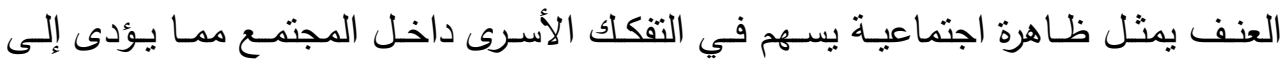
تقويضه ويؤثر في مظهره الحضاري. - من خلال وسائل الإعلام، يمكن نشر المفاسد التي يؤدى إليها العنف داخل المجتمع، يكون

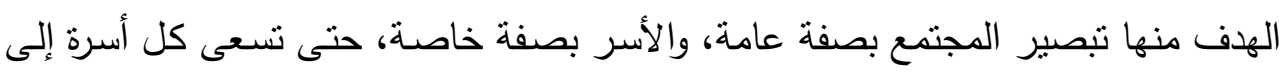
التعرف على مشكلات الأبناء، وتنهض بطرق التربية والتنشئة الاجتماعية السليمة، للتربية الصحيحة التي تبعد وتتأى بهم عن العنف والطرق المؤدية.

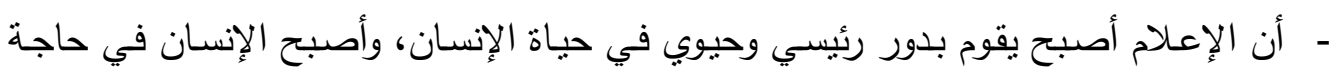

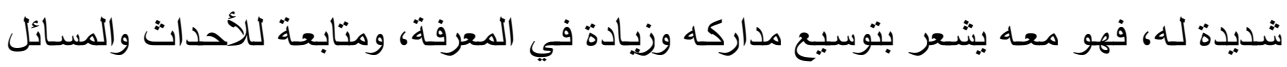

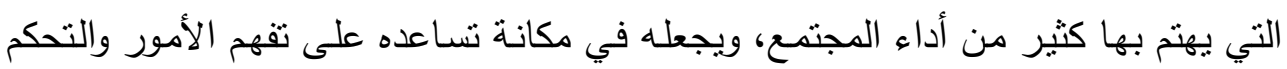
في التصرفات بسبب الزيادة في النقافة والمعرفة من خلال الوسائل الإعلامية.

\section{مقترحات وتوصيات البحث}

$$
\text { توصل البحث إلى عدد من التوصيات والمقترحات: }
$$

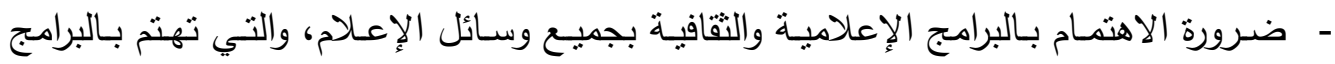

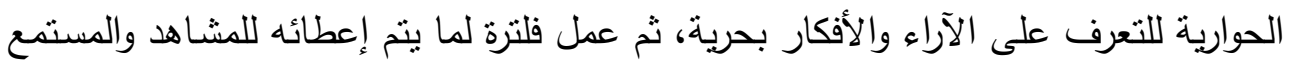

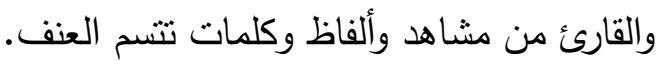




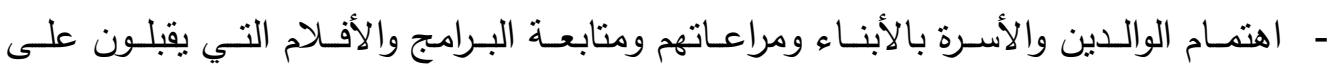

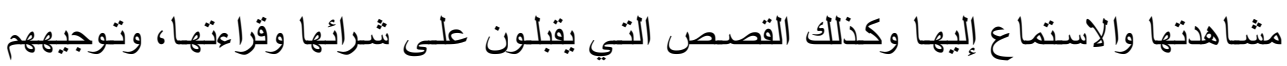

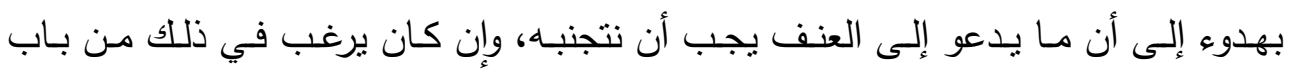

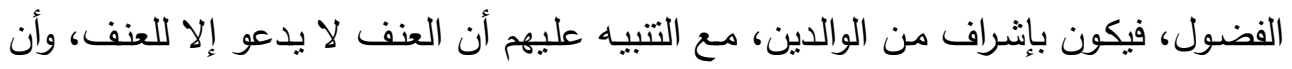
الإسراف في الثئئ غير مرغوب فيه وغير مطلوب حتى لا تصل لمن لما لا يحمد عقباه.

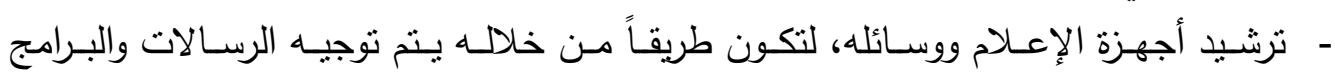

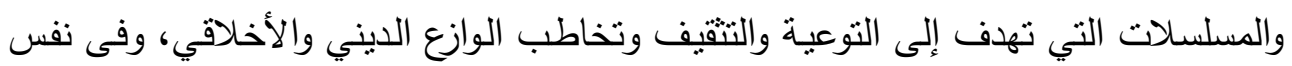

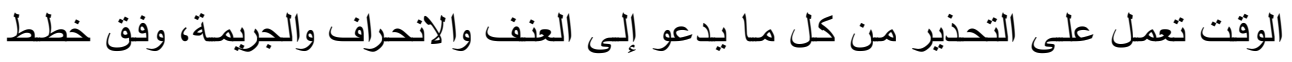

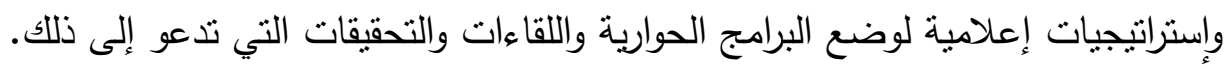

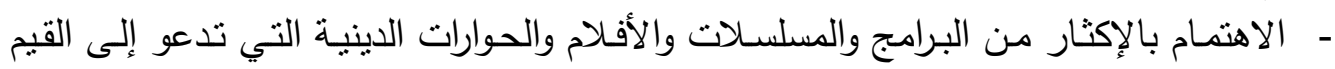

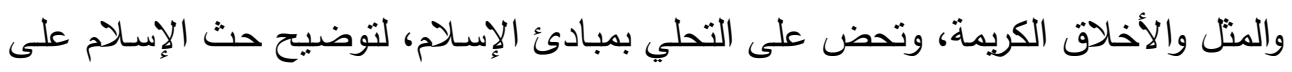

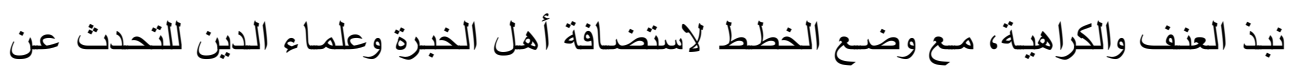
العنف وآثاره وكيفية التخلب عليه. - - التأكيد من خـلال مؤسسات التربية والتعليم على التزام الطلاب بـالقيم الأخلاقية والمسلكية،

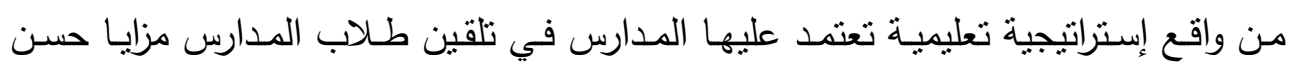

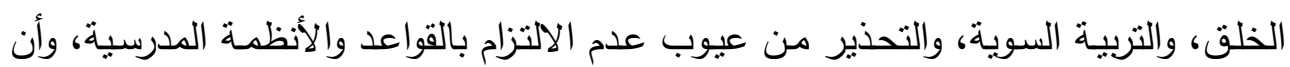

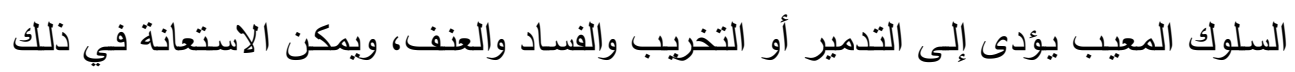

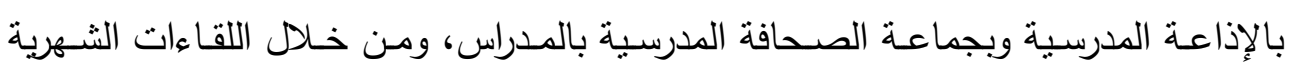
بأولياء الأمور لحث أبنائهم على البعد عن العنف.

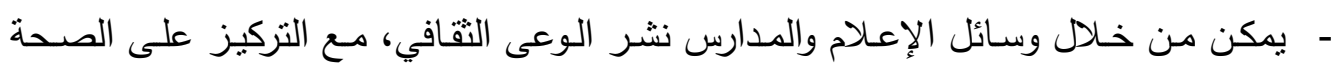

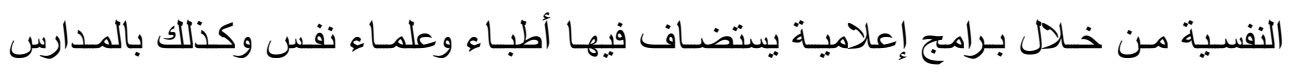

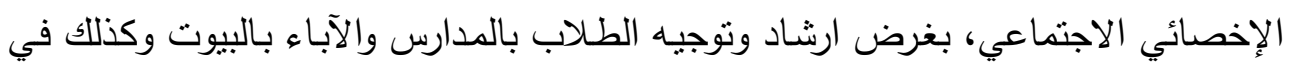

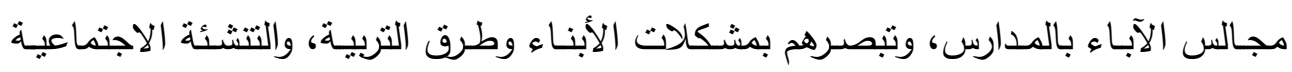

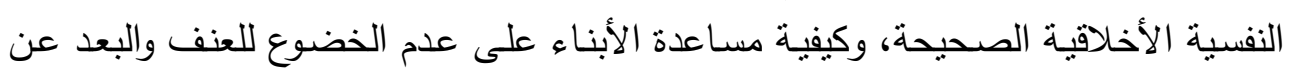
السلوك العدواني وما يؤثز على النفس. 


\section{المراجع والمادر}

(1) خالد إمـام، مـا ينشـر عن التعذيب ... حـالات فرديـة (القـاهرة، مجلـة الثـرطة، العدد بس، وزارة الداخليـة،

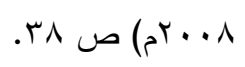

(r) خالد عبد الحميد خربوش، دور القيم الانضباطية في إعداد رجل الأمن، بحث غير منشور (القاهرة، مركز

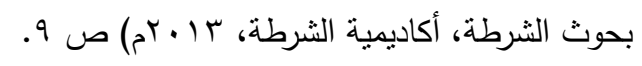

(r) محمد دحمانى، دور وسـائل الإعـلام في محاربـة العنف، رسـالة ماجستير غير منشـورة (الجزائر، جامعـة

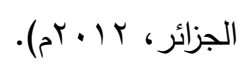

(؛) هدى بنت يوسف الصـيب، دور وسـائل الإعـلام في مكافحة العنف، (المملكة العربيـة السعودية، صحيفة

$$
\text { الرياض، العدد } 9 \text { r (T (ا، r ( • rم). }
$$

(o) هشام رشدي خيراله، تعرض الثباب الجامعي لأحداث العنف السياسي في الصحف والتليفزيون وعلاقته بقلق

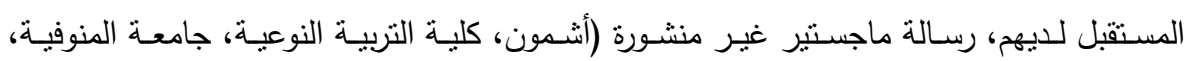

$$
\left.\cdot()^{2} \cdot\right) \text {. }
$$

(1) أميرة جابر هاثم، أثر برنـامج إرشـادي وقائي في خفض سلوك العنف لدى طلبـة الجامعـة، بحث منشور

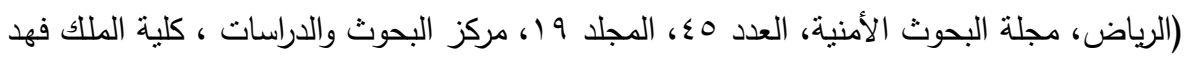

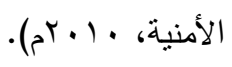

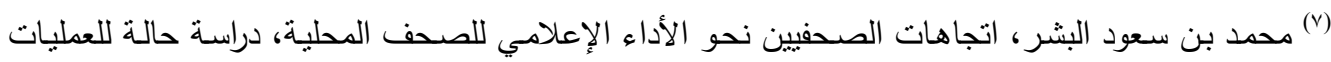

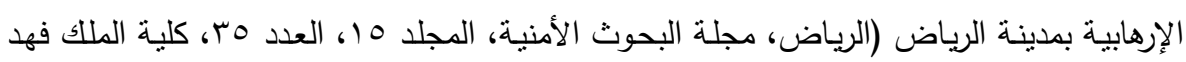

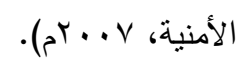

(8) Julie. Webber: "Virtual Security Regimes and Disciplining Youth", (Honolulu, Hawaii, 2005).

(9) هناء السيد محمد، معالجة الصحف المصرية لأحداث محرم بك الطائفية عام 0 . . بم، دراسة تحليلية مقارنة

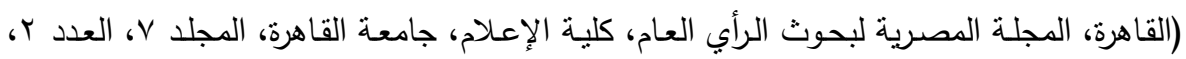

$$
\cdot(\text { ) }
$$

(10) Abdulrahman Alzuhayyon: Construction of Saudia Arabia's Social Reality before and after September 11, 2001 by us mainstrean Television News Organization in Relation to united states Government Officials' News Framing the University of Memphis's, 2005.

${ }^{(11)}$ Sparks, G. G. The Difference between Fear of Victimization and The Probability of Being Victimized, Journal of Broad Costing and Electronic Media, Vol. 34 (3), 1990.

(ז') حسن علوان، موضوع الإرهاب في الفضائيات العربية- دراسة دكتوراه غير منشورة، (الدانمارك، كلية الآداب

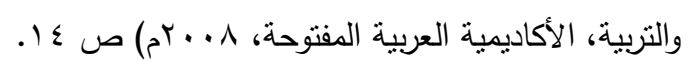

(13) Gunter B. and Jill L, M. Children and television: the one eyed. monster, London: Rutledge, 1990, p. 78. 


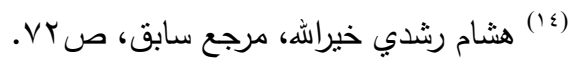

(10) هالـة غالب، اتجاهـات نطور جرائم السرقة بـالإكراه في المجتمـع المصـري، دراسـة تحليلية، الفترة مـا بين

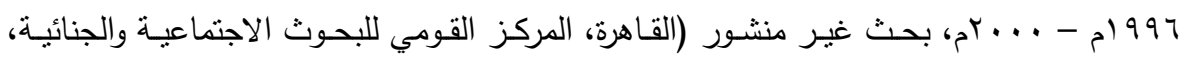

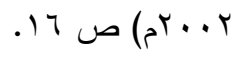

(1) درويش زين العابدين، علم النفس الاجتماعي، أسس وتطبيق (القاهرة، دار الفكر العربي، 999 (م) صلحـ.

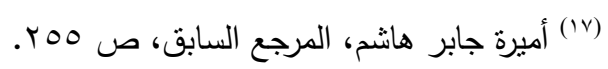

(18) Bafree.net/aLhisn/Showthread.php?t=63828\&page=1.13/10/2013.

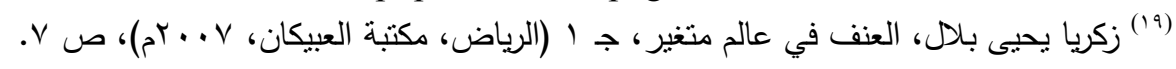

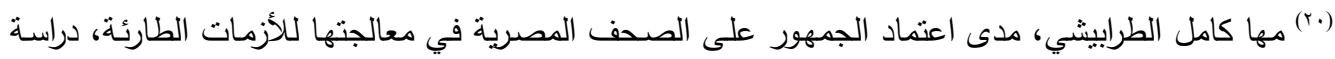
حالة على حادث سقوط الطائرة المصرية (القاهرة، المجلة المصرية لبحوث الرأي العام، كلية الإعلام،

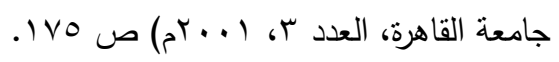

(21) WWW.zmzm.org/index ar.php?op=article\&id=54-24-10-2013

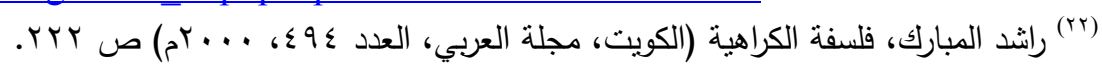

(23) Carlen, L. R (1996): Attachment relationship among children with aggressive behavior problems: the role of disorganized early attachment patterns, Journal of Counseling \& Clinical Psychology, Vol. 64, No. 1, pp. 64- 73.

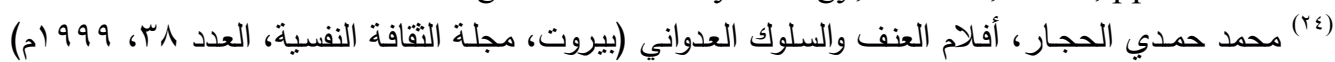

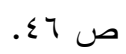

(ro) عبد الملك ردمان الدفاثى، تطوير تكنولوجيا الاتصال وعولمة المعلومات (القاهرة، المكتب الجامعي الحديث،

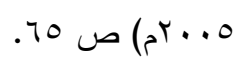

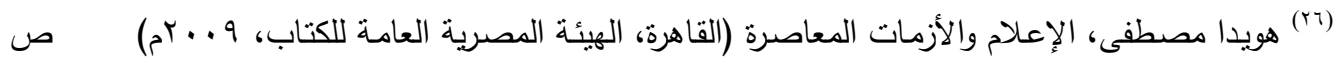

$$
\text { ص ص }
$$

سوزان يوسف القليني، مدى اعتماد الصفوة المصرية على التليفزيون في وقت الأزمات، دراسة حالة على

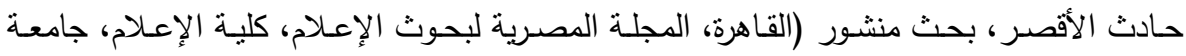

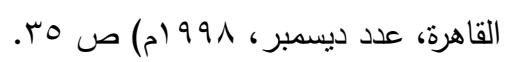

(28) www.bshra.com/b77/alonfthadalmara.htm.24-10-2013

(29) www.ahewar.org/debat/show.art.asp?aid $=134581.24-10-2013$

(30) yomgedid.kenanaonline.com/posts/98664.24-10-2013

(31) www.alawsatnews.com/4041/news/read/815058/1.html.24-10-2013

(32) www.thara-sy.com/thara/modules/news/article.php?storyid=bb.24-10-2013

(rr) حسن عبد الحميد حسن، التفكك الأسرى ودوره في الانحلال الاجتماعي، بحث منشور (المنوفية، مجلة كلية

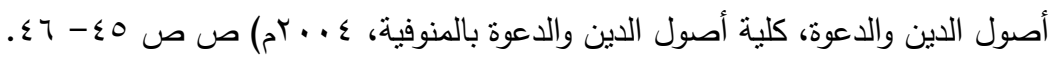

(๕ץ) جابر محمد عبد الموجود، الإعلام وتتمية الوعي البيئي من منظور إسلامي، بحث منشور (القاهرة، مجلة

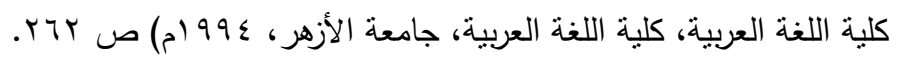


(ror) ولبور شرام، أجهزة الإعلام والتتمية الوطنية، نرجمة محمد فتحي (القاهرة، الهيئة المصرية للتأليف والنشر،

$$
\begin{aligned}
& \text {.IVI מ (a) }
\end{aligned}
$$

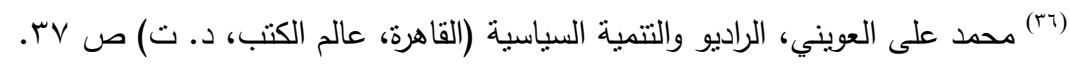

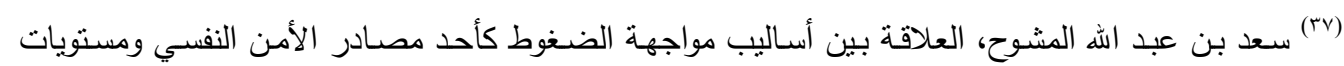
الإشباع الوظيفي لدى عينة من العسكريين في المملكة العربية السعودية، بحث منشور (الرياض،

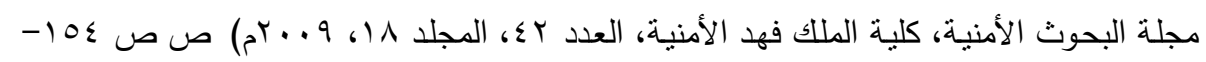

$$
.170
$$

(†^) مدحت أبو بكر محمد، التخطيط للإعلام الأمني باستخدام شبكة الإنترنت، رسـالة دكتوراه غير منشورة

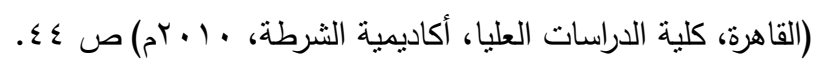

(39) www.alawan.org/عناصر - إستراتيجية.html.25-10-1023

(40) shrsc.com/articles/231.htm.25-10-2013.

(1) مفلح بن دخيل الأكلبي وآخرون، استراتيجية مقترحة لغرس قيم الأمن الفكري لدى الطلاب لتحصينهم ضد

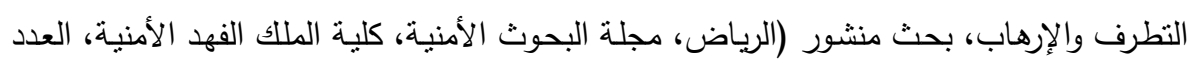

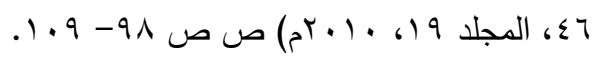

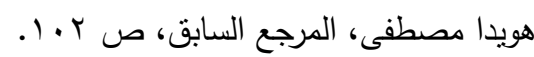

(43) Www.october.mog.com/Issues/1912/artDetail.asppArt1D=139148.23-10-2013

(44) www.newseegypt.com/index.php./ar/docswomen/pslara/445-vaw3ara.25-10-2013

${ }^{(45)}$ Olislah.ma./2011-04-10-21-55-26/2012-11-12-25-08/25857.html.23/10/2013

(46) $\mathrm{http}: / /$ site.google.com/site/sozisalih/sara-3.25-10-2013

$$
\begin{aligned}
& \text { أميرة جابر هاشم، المرجع السابق، ص ror) }
\end{aligned}
$$

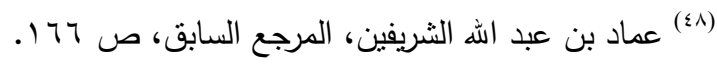

(9) ممدوح عبد الحمبد عبد المطلب، الاتجار بالبشر، بحث منشور (الرياض، مجلة البحوث الأمنية، كلية الملك

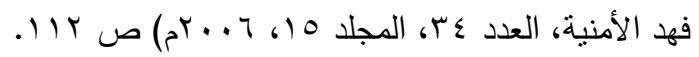

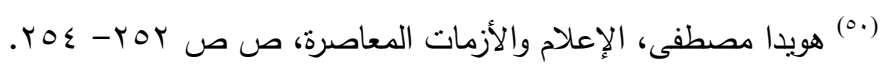

